
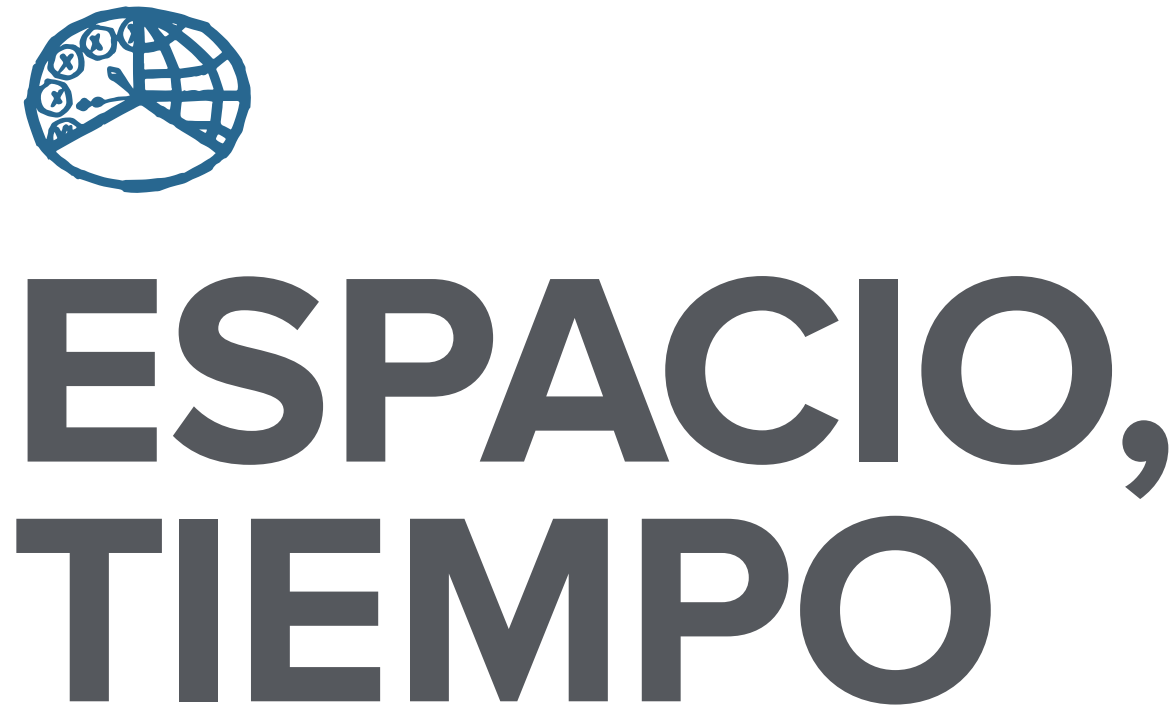

AÑO 2013

NUEVA ÉPOCA

ISSN 1130-4715

E-ISSN 2340-1478
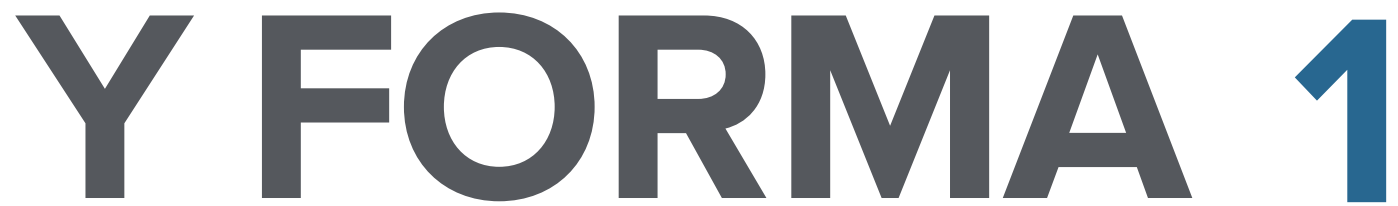

SERIE VII HISTORIA DEL ARTE

REVISTA DE LA FACULTAD DE GEOGRAFÍA E HISTORIA 

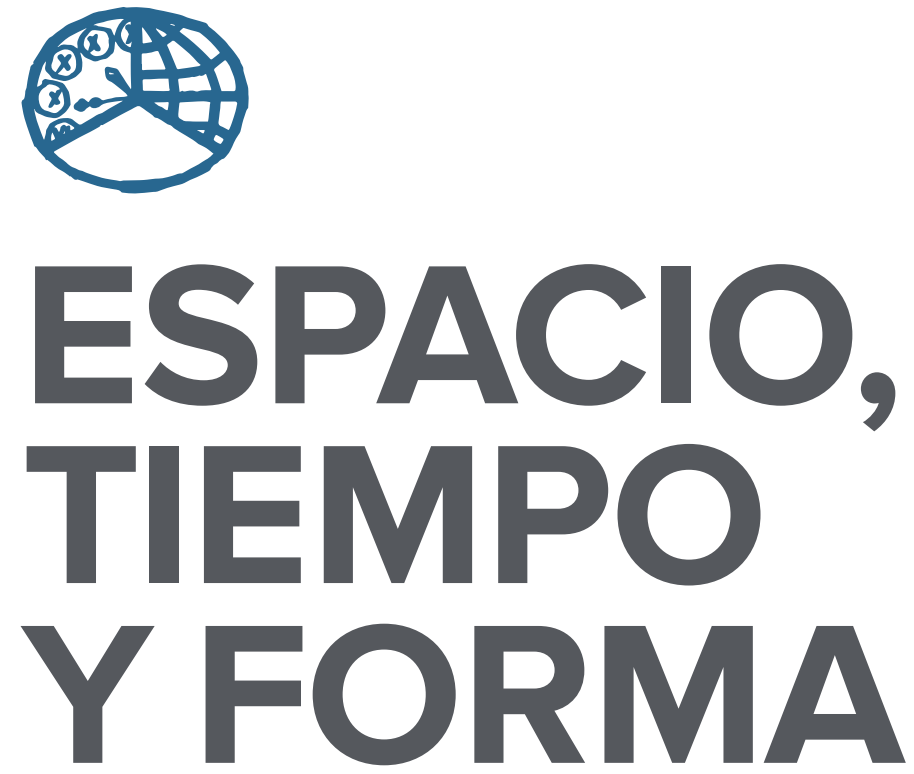

AÑO 2013

NUEVA ÉPOCA

ISSN $1130-4715$

E-ISSN 2340-1478

SERIE VII HISTORIA DEL ARTE

REVISTA DE LA FACULTAD DE GEOGRAFÍA E HISTORIA

http://dx.doi.org/10.5944/etfvii.1.2013

\section{UกED}

UNIVERSIDAD NACIONAL DE EDUCACIÓN A DISTANCIA 
La revista Espacio, Tiempo y Forma (siglas recomendadas: ETF), de la Facultad de Geografía e Historia de la UNED, que inició su publicación el año 1988, está organizada de la siguiente forma:

$$
\begin{aligned}
& \text { SERIE I - Prehistoria y Arqueología } \\
& \text { SERIE II - Historia Antigua } \\
& \text { SERIE III - Historia Medieval } \\
& \text { SERIE IV - Historia Moderna } \\
& \text { SERIE V - Historia Contemporánea } \\
& \text { SERIE VI - Geografía } \\
& \text { SERIE VII - Historia del Arte }
\end{aligned}
$$

Excepcionalmente, algunos volúmenes del año 1988 atienden a la siguiente numeración:

$$
\begin{aligned}
& \mathrm{N}^{\circ} 1 \text { - Historia Contemporánea } \\
& \mathrm{N}^{\circ} 2 \text { - Historia del Arte } \\
& \mathrm{N}^{\circ} 3 \text { - Geografía } \\
& \mathrm{N} .^{\circ} 4 \text { - Historia Moderna }
\end{aligned}
$$

ETF no se solidariza necesariamente con las opiniones expresadas por los autores.

Espacio, Tiempo y Forma, Serie vII está registrada e indexada, entre otros, por los siguientes Repertorios Bibliográficos y Bases de Datos: DICE, ISOC (CINDOC), RESH, IN-RECH, Dialnet, e-spacio, UNED, CIRC, MIAR, FRANCIS, PIO, Ulrich's, SUDOC, 2DB, ERIH (ESF).

\author{
UNIVERSIDAD NACIONAL DE EDUCACIÓN A DISTANCIA \\ Madrid, 2013 \\ SERIE VII · HISTORIA DEL ARTE (NUEVA ÉPOCA) N. ${ }^{\circ} 1,2013$ \\ ISSN $1130-4715 \cdot$ E-ISSN 2340-1478 \\ DEPÓSITO LEGAL \\ $M-21.037-1988$ \\ URL \\ ETF VII · HISTORIA DEL ARTE · http://revistas.uned.es/index.php/ETFVII \\ DISEÑO Y COMPOSICIÓN \\ Ángela Gómez Perea · http://angelagomezperea.com \\ Sandra Romano Martín · http://sandraromano.es \\ Impreso en España · Printed in Spain
}

(c) (1) (8) Esta obra está bajo una licencia Creative Commons

Reconocimiento-NoComercial 4.0 Internacional. 


\title{
DE LA ALJAMA A LA PRIMITIVA \\ CONSTRUCCIÓN GÓTICA. \\ REFLEXIONES A PROPÓSITO \\ DE LA CATEDRAL DE JAÉN \\ EN ÉPOCA BAJOMEDIEVAL
}

\section{FROM THE GREAT MOSQUE \\ TO THE FORMER GOTHIC CONSTRUCTION. \\ SOME OBSERVATIONS ON JAÉN'S CATHEDRAL DURING THE LATE MIDDLE AGES}

Manuel Jódar Mena

Recibido: 6/05/2013 - Aprobado: 7/10/2013

http://dx.doi.org/10.5944/etfvii.1.2013.6415

\begin{abstract}
Resumen
Los documentos escritos, los textos cronísticos y las fuentes bibliográficas son casi los únicos medios que disponemos los historiadores para acercarnos al conocimiento sobre los orígenes constructivos de la Catedral de Jaén, intentando, a través de su correcta lectura e interpretación, recuperar esa parte del desaparecido pasado arquitectónico. Con este trabajo, se pretende, partiendo de una necesaria revisión historiográfica, reflexionar sobre algunas de las cuestiones fundamentales de la primitiva fábrica de la catedral giennense, además del destacado papel de promoción desarrollado por distintos prelados durante los siglos XIII-Xv.
\end{abstract}

Palabras clave

Catedral; Jaén; gótico; siglos xııI-Xv; Crónica del Condestable Iranzo

\section{Abstract}

The only way historians have of investigating the structural origins of Jaén's Cathedral are documents chronicles and bibliographical sources. Through their analysis and interpretation it is possible to recover that part of it is lost architectural history. With this paper we aim to reveal different aspects related to the former masonry and the significant role played by some bishops during the promotion and development of this building during the $13^{\text {th }}$ and $15^{\text {th }}$ centuries.

\section{Keywords}

Cathedral; Jaén; gothic style; $13^{\text {th }}-15^{\text {th }}$ centuries; Constable Iranzo Chronicle

1. Profesor Contratado Doctor, Universidad de Jaén (majodar@ujaen.es). 


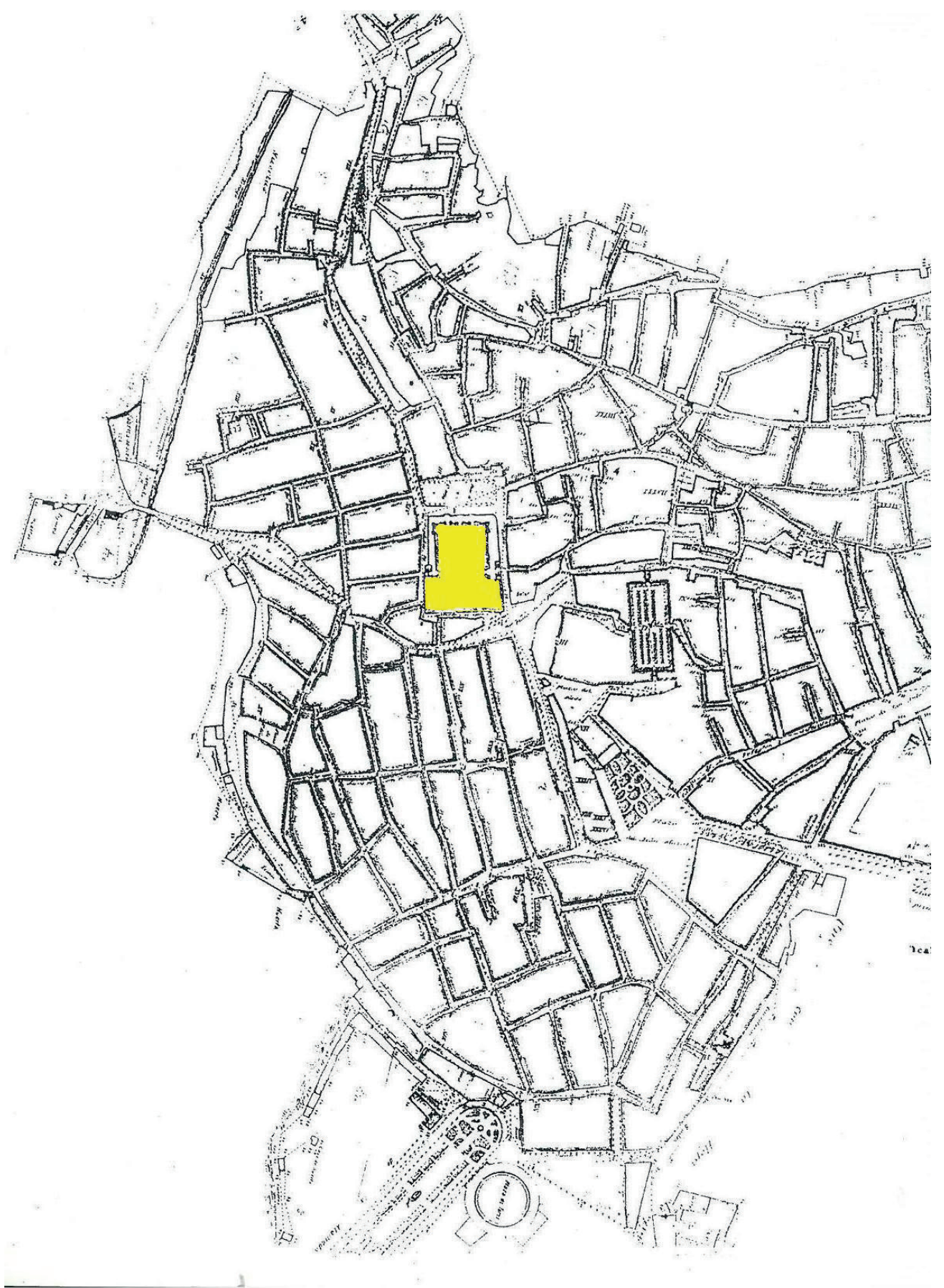

FIGURA 1. PLANO DE SITUACIÓN DE LA CATEDRAL DE JAÉN EN SU ESPACIO URBANO Archivo Histórico Municipal de Jaén. Plano de Jaén (1892). 


\section{LA LABOR DE DESEMPEÑADA POR LOS OBISPOS DON NICOLÁS DE BIEDMA (1368-1378) Y DON GONZALO DE ESTÚÑIIGA (1423-1456)}

Desde la purificación de la mezquita-catedral de Jaén (I246) hasta los inicios de la primitiva construcción gótica, con el comienzo de la prelatura de don Nicolás de Biedma - junio de $1369^{2}$-, pasaron I23 años en los cuales no existe noticia alguna sobre la adaptación y transformación del edificio islámico en catedral cristiana.

La situación de paz del reino de Jaén era un tanto efímera, puesto que los territorios fronterizos se encontraban en continuo estado de tensión como consecuencia de su estratégica posición. A esto hay que sumar los problemas acontecidos entre Pedro I, apodado el Cruel, y su hermanastro, Enrique il. Esta particular coyuntura propició una serie de conflictos bélicos en los que se vieron intencionadamente involucrados los nazaríes, encabezados por Muhammad v. Las consecuencias para la ciudad de Jaén, a raíz de las aportaciones de la Crónica de Ayala (siglo xiv), fueron funestas:

...E los moros pusieron fuego a toda la cibdad e a las iglesias, e derribaron las puertas mayores de la cibdad e gran parte de los muros, donde fue estragada e rescibió mucho daño e grand deshonra la dicha cibdad de Jaén...»³ (FIGURA 1)

Con independencia de que el relato pueda aportar algunos matices un tanto exagerados, las fuentes árabes, en consonancia con las aportaciones de la crónica de Ayala, describen con cierta virulencia cómo el arrabal de Jaén fue totalmente saqueado, y cómo fueron destruidos y quemados los templos y las casas de piedad 4 .

El motivo principal de tales destrucciones fue el traslado del enfrentamiento entre Pedro i y Enrique il al reino de Jaén. El primero, aliado con Muhammad v, destruyó los archivos de la ciudad para hacer desaparecer los títulos de privilegios y propiedades de los aliados de su adversario, desposeyéndoles así de todas sus mercedes 5 . En todo caso, quien más beneficio pudo sacar de los acontecimientos fue el soberano nazarí, aprovechando su acuerdo con Pedro i para llevar a cabo, según palabras de Torres Jiménez, «su particular guerra islamista ${ }^{6}$.

2. A pesar de que fue nombrado obispo el 26 de julio de 1368, la sede permaneció vacante hasta junio de 1369, con lo cual, materialmente es imposible que se atisbara rasgo alguna de reforma en la Catedral de Jaén con anterioridad a esta fecha.

3. RoselL, Cayetano: Crónicas de los reyes de Castilla [Texto impreso]: desde don Alfonso el Sabio hasta los Católicos don Fernando y doña lsabel. Madrid. Sucesores de Hernando 1919-1931. Madrid, Atlas, pp. 582-583.

4. IBN AL-JATIB, Muhammad: Historia de los Reyes de la Alhambra. El resplandor de la luna llena (Al-lamha al-badriyya). Granada, Universidad, 1998, p. 127.

5. Rodríguez Molina, José: El Reino de Jaén en la Baja Edad Media. Aspectos demográficos y económicos. Granada, Universidad, 1978, p. 140. Turatti Guerrero, Rafael: «La quema de los archivos de Jaén en 1368 ¿Moros de Granada o Pedro I?», en TORo Ceballos, Francisco \& Rodríguez Molina, José: (coords.): Historia, tradiciones y leyendas en la frontera: IV Estudios de Frontera, Alcalá la Real, 2001. Jaén, Diputación Provincial, 2002, pp. 590-591.

6. TORRES JimÉNEZ, Juan Carlos: «El ataque nazarí a Jaén de 1367-1368 y las religiosas del convento de Santa Clara», Giennium, (2007), p. 461. 
En los textos cronísticos castellanos los hechos aparecen aglutinados en torno a los años 1367-68. Según los datos cronológicos de las fuentes árabes, probablemente estos ataques se produjeron entre el i9 y el 23 de septiembre de 1367 . No obstante, a comienzos de 1368 parece que se materializaron nuevas oleadas en las que se arrasó lo poco que quedaba sin destruir ${ }^{7}$.

Con este trabajo se va a tratar de analizar hasta qué punto estos hechos condicionaron el devenir histórico, arquitectónico y urbano de la ciudad de Jaén. Probablemente, a pesar de las lagunas documentales, estos enfrentamientos se saldaron con grandes pérdidas económicas y materiales, tal y como en su momento repararon, entre otros, Rus Puerta (I6oI $)^{8}$ o Martínez de Mazas (I794) ${ }^{9}$, o como posteriormente ha asumido la historiografía tradicional.

En cualquier caso, después de los daños provocados en la mezquita-catedral, ¿merecería la pena reconstruirla? Probablemente no, sobre todo teniendo en cuenta las dificultades generadas en la adecuación del edificio islámico en templo cristia$\mathrm{no}^{\mathrm{IO}}$, eso a pesar de que, según las descripciones conservadas, ambas tuvieran igual número de naves ${ }^{\text {II }}$. En todo caso las aportaciones de Ximena Jurado (I654) ${ }^{12}$, como ha sugerido Salvatierra Cuenca ${ }^{13}$, parecen revelar la inversión del eje de su estructura arquitectónica ${ }^{\mathrm{I}}$. No obstante, este proceso de adaptación, entre otras cosas, llevaría implícito la incorporación del coro al eje de las naves de la primitiva aljama, la adecuación de sus accesos, la construcción de las capillas, la edificación de otras dependencias (sacristía, claustro, biblioteca, archivo) y finalmente la conversión del alminar en torre campanario. Todas estas cuestiones dificultarían, incluso aún más si cabe, la remodelación de la derruida mezquita-catedral. Por estos motivos, me inclino en apoyar la hipótesis de la destrucción, hasta los cimientos,

7. Idem, p. 477.

8. Biblioteca Nacional de España (BNE), Manuscrito 5582. De Rus Puerta, Francisco: Obispos de Jaén. 16o1. Fols. 196r., 196v.

9. Martínez De MazAs, José: Retrato al natural de la ciudad de Jaén y término de Jaén. Barcelona, Imprenta D. Pedro de Doblas, 1794. Reimpresión: Barcelona, El Albir, 1978, pp. 169-171.

10. Respecto a la conversión de mezquitas en catedrales resulta de gran interés la comparativa con las aljamas de Córdoba, Granada o Sevilla, para lo cual, resulta de gran interés: LAGUNA PAUL, Teresa: «La aljama cristianizada. Memoria de la catedral de Santa María de Sevilla», en vV.AA.: Metropolis Totius Hispaniae. 750 Aniversario de la Incorporación de Sevilla a la Corona de Castilla. Sevilla, Ayuntamiento, 1998, pp. 41-71. Almagro GorbeA, Antonio: «De Mezquita a Catedral. Una adaptación imposible», en JımÉnEz MARTín, Antonio (ed.): La piedra postrera. Simposium Internacional sobre la Catedral de Sevilla en el contexto del gótico final. Sevilla, Taller Dereçeo, 2007 pp. 24-31.

11. Levi-ProvençAL, Evariste: La Péninsule Ibérique au Moyen Age, d'après le Kitab ar-Rawod al mi'tar fi habar al-aktar d'Ibn 'Abd-al-Mun'im al-Himyari [Texto impreso]: texte arabe des notices relatives à l'Espagne, au Portugal et au Sud-Ouest de la France. Leiden, E.J. Brill, 1938, p. 88.

12. «Avía estado esta iglesia hasta su tiempo desde que esta Ciudad de laén se ganó por el Santo Rey don Fernando, en la forma antigua que tenía de Mezquita en el de los Moros, y el Obispo Don Nicolás de Biedma la derribó y edificó de labor más hermosa, y capaz, y la dispuso de la manera que los cristianos tenemos en las Fábricas de los templos». De Ximena Jurado, Martín: Catálogo de los Obispos de las Iglesias Catedrales de Jaén y Anales Eclesiásticos de este Obispado. Edición facsímil. Granada, Universidad, 1991. En Madrid: por Domingo Garcia y Morràs, 1654, pp. $364-365$.

13. Salvatierra Cuenca, Vicente: La formación de la ciudad de Jaén. De Ibrahim ibn Hamusk al Condestable Iranzo. Jaén, Instituto de Estudios Giennenses, 2007, p. 42.

14. Tradicionalmente las mezquitas andalusíes presentaban el muro de la quibla con una orientación $\mathrm{N}-\mathrm{S}$, mientas que las cabeceras de los templos occidentales articulaban este espacio en torno al eje E-W. 
de la construcción precedente y la posterior erección, sobre el derruido solar, de la primitiva catedral gótica ${ }^{15}$.

A tenor de lo expuesto, la justificación de la destrucción de la mezquita como medida de manifestación de la supremacía de la fe cristiana sobre las tradiciones islámicas carece de fundamento. Eso a pesar de que no falten en las fuentes escritas argumentaciones cargadas de evocaciones ciertamente maurofóbicas. Como muestra puede servir la descripción que hace Núñez de Sotomayor (I66I) sobre los motivos que llevaron a don Nicolás de Biedma a construir el nuevo edificio:

\footnotetext{
...Quedaron en pie aquellas paredes si antes torpemente violadas ya con asistencia de Dios ennoblecidas y desde el mismo hasta el de 1368 fueron depósito divino de Dios Sacramentado. Y por no encomendar sagradas torres a los que avían sido tan falsos y corrompidos cimientos el abrasado zelo del Ilustrísimo Señor Don Nicolás de Viedma, digníssimo obispo de Jaén las demolió sin permitir ni aún la memoria de sus fundamentos dejando sepultada la fama de aquella máquina infiel en su despreciable ruina y labrando sobre las cenizas de su olvido un templo nuevo con aclamación católica restituyo su decorosa fábrica e y su antigua forma aplaudida de la Christiandad... ${ }^{16}$.
}

Este tipo de relatos podría ser comparado con algunos de los encontrados en crónicas, memoriales o cantares medievales, en los que se manifiesta un cierto sentimiento de repulsa hacia lo islámico, hecho que lejos de mitigarse en las centurias siguientes, se acentuaría por diversos factores: la celebración del Concilio de Trento, los conflictos acontecidos entre los Austrias y los turcos otomanos, e incluso, en la frontera, con los problemas generados entre los conversos y los moriscos granadinos en el siglo Xvil ${ }^{17}$.

Las destrucciones en la ciudad de Jaén durante los años I367-68 se produjeron después del mandato del obispo don Alonso Pecha (I359-I368). Bajo su prelatura se celebró el primer sínodo diocesano documentado (I368). Pese a que Montijano Chica diga que las constituciones promulgadas se encuentran en el Archivo Histórico Diocesano de Jaén, en «primorosa letra gótica» ${ }^{18}$, lo cierto es que en la actualidad no queda testimonio alguno de su presencia. Existen noticias del sínodo a través de las referencias que aparecen en las sucesivas constituciones promulgadas con posterioridad ${ }^{19}$ (FIGURA 2).

Su interés estribaría en la posibilidad de tener algún dato sobre la promoción de las obras catedralicias en la época en la que se publicó (I368), y el conocimiento de las ayudas económicas en materia constructiva. Además, probablemente ofrecería

15. Cuestión que desde un primer momento había sido planteada por Galera Andreu. Véase: GALERA ANDREU, Pedro Antonio: La Catedral de Jaén. Madrid, Everest, 1983, p. 3.

16. NúÑEZ de SOtomayor, Juan: Descripción panegyrica de las insignes fiestas que la S. Iglesia Catedral de laén celebró en la traslación del S. Sacramento a su nuevo y sumptuoso Templo por el mes de octubre de 1660. Málaga, impreso por Mateo López Hidalgo, 1661, p. 3.

17. Sobre todos estos factores ha planteado interesantes reflexiones: TURATTI GUERRERo, Rafael: op. cit. p. 580.

18. Montijano Chica, Juan: Historia de la Diócesis de Jaén y sus obispos. Jaén, Instituto de Estudios Giennenses, 1986, p. 21.

19. Martínez Rojas, Francisco Juan: Aproximación a la Historia de la Iglesia. Jaén, Obispado, 1999, pp. 191-193. 


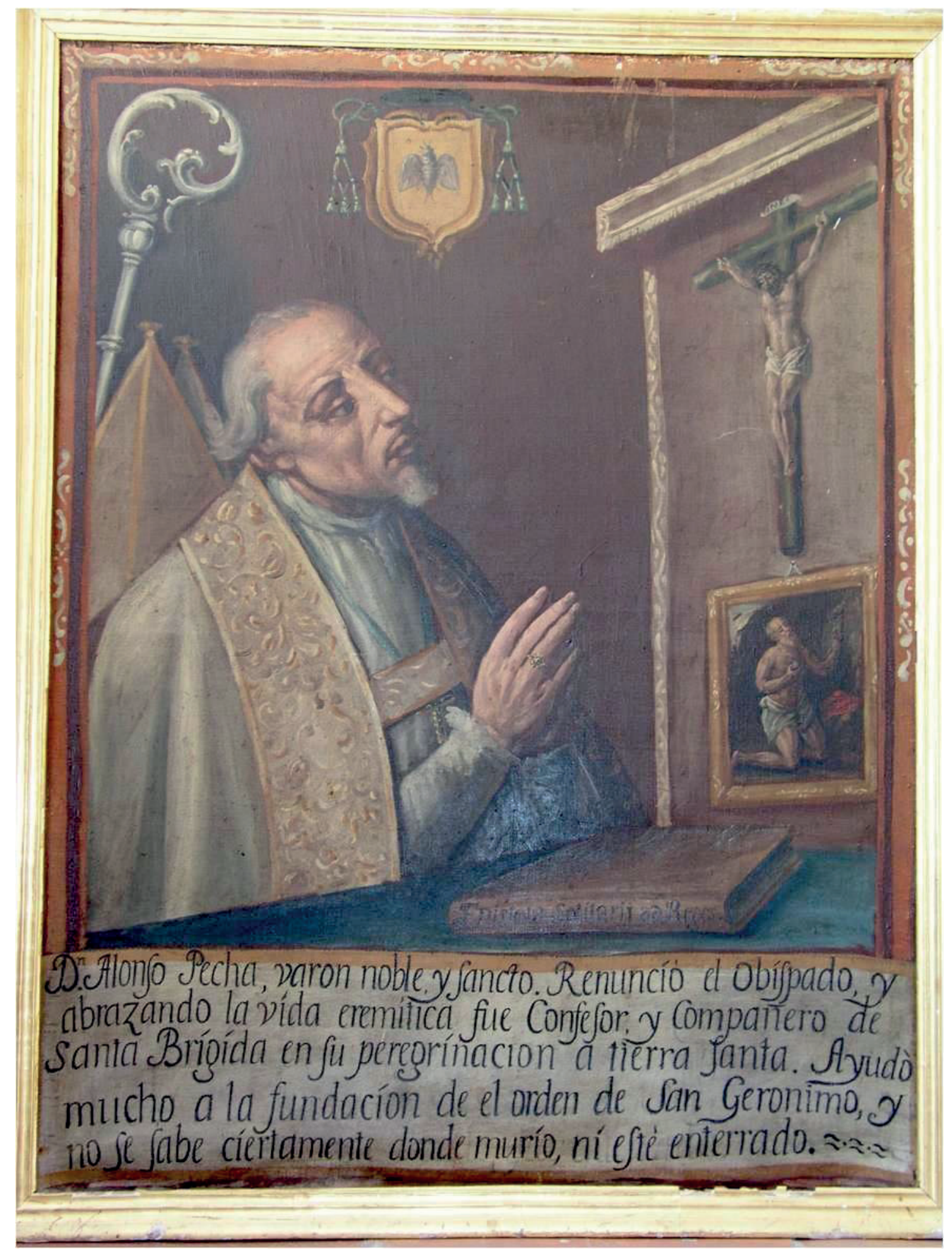

FIGURA 2. DON ALONSO PECHA

Archivo Histórico Diocesano de Jaén. 


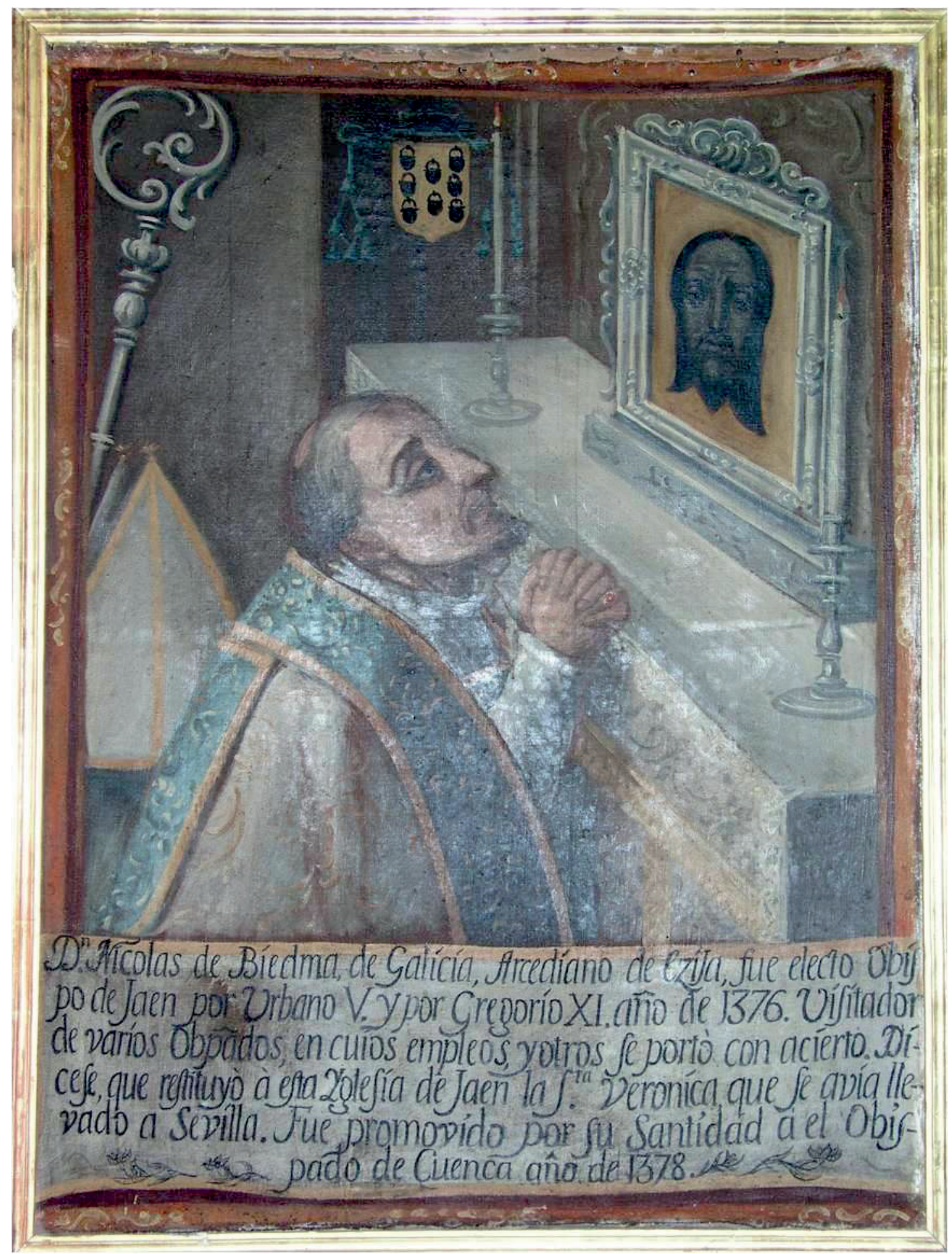

FIGURA 3. DON NICOLÁS DE BIEDMA

Archivo Histórico Diocesano de Jaén. 
información sobre el aprovechamiento de las mezquitas, y el proceso de adaptación de su espacio a las nuevas necesidades de culto impuestas por la liturgia cristiana.

Los enfrentamientos entre Pedro I y Enrique il también generaron un desconcierto en la Diócesis, hasta el punto de que entre los años I367-I368 se conservan documentos en los que firmaron como máximos responsables de la Diócesis dos personajes de forma simultánea. Por una parte don Alonso Pecha, en aquellos acuerdos favorables a Enrique il y por la otra, otro prelado, de nombre Andrés, confirmando algunos privilegios de Pedro I en el Reino ${ }^{20}$, todo ello, lógicamente, en función de los intereses particulares de los distintos bandos.

El momento en el que se llevó a cabo el comienzo de la construcción de la remodelada catedral gótica coincidiría con la incorporación de don Nicolás de Biedma ${ }^{2 \mathrm{r}}$ al frente de la Diócesis, es decir, a partir de junio de I369 (FIGURA 3).

Rus Puerta describe de forma muy gráfica algunos de los cometidos principales desarrollados durante su prelatura, incidiendo especialmente en el arreglo de los desperfectos ocasionados durante el enfrentamiento entre monarcas castellanos:

Vino pues don Nicolás de Biedma a su obispado, y hallándolo en la forma que se ha referido. Puso luego todo su cuidado assí en visitarlo, y consolar a sus feligreses, como en reparar las Iglesias y Templos que los moros avían destruido, principalmente su Catedral en la Ciudad de Jaén ${ }^{22}$.

No cabe duda de que el principal obstáculo que debió encontrar en el camino para recomponer los desperfectos ocasionados durante la razzia de los años I367-68 fue el reunir los caudales suficientes para hacer frente a tan costosa empresa. Por otra parte, debía ser contemplada la posibilidad de que los conflictos volvieran a reproducirse. Por eso, sabedor de las dificultades a las que se enfrentaba, adoptó una serie de medidas tendentes no sólo a reducir los gastos, sino también a aumentar los ingresos, tal y como se desprende de la lectura del siguiente fragmento de Viaje de España de Antonio Ponz (I79I):

Para su remedio en 2 de marzo de 1371 el Señor Don Nicolás de Biedma, Obispo de Jaén, con acuerdo de su Deán y Cabildo, reduxo esta Iglesia a quatro Dignidades, Tesorero, Chantre, Arcipreste y Vicario, y a ocho Canónigos, quitando las Raciones que había, respecto a la pobreza en que se hallaba por la desolación que había causado los Moros en 1368, y les concedió ciertos donativos, de los quales llevasen la mitad de los diezmos, acatando que la dicha Iglesia era la más honrada y mayor que ninguna23.

20. Rivera, Juan Francisco: «Notas y documentos para el episcopologio de la Sede de Baeza-Jaén, los siglos XIII y xIV», Boletín del Instituto de Estudios Giennenses, 80 (1974), p. 43.

21. Aunque fue nombrado obispo de Jaén el 26 de julio de 1368, la sede permaneció vacante hasta su incorporación en junio de 1369. Idem. p. 45.

22. BNe, Manuscrito 5582. De Rus PuerTA, Francisco: op. cit. Fol. 196 r.

23. PONZ, Antonio: Viage de España, en que se da noticia de las cosas más apreciables, y dignas de saberse, que hay en ella. Edición facsímil: Madrid, Viuda de D. Joaquín Ibarra, 1791, p. 124. 
Las principales acciones desarrolladas para el aumento de los caudales de la Diócesis estuvieron orientadas hacia el crecimiento de las donaciones. En este sentido, la historiografía ha valorado el esfuerzo desempeñado por Don Nicolás de Biedma en depositar en la catedral la reliquia del Santo Rostro, cuya extendida veneración ${ }^{24}$ se ha mantenido intacta hasta nuestros días. A pesar de que podría ser considerado como un factor clave para el resurgir económico de la fábrica del templo mayor ${ }^{25}$, se carece de documentos que así lo confirmen. Además, los datos históricos que se disponen apuntan que hasta la segunda mitad del siglo xv no se tiene conciencia de su trascendencia, extendiéndose su particular devoción a lo largo del siglo $\mathrm{XvI}^{26}$. No obstante, podría pensarse que el propio prelado ya concibiera la enorme repercusión que podría alcanzar esta reliquia para la historia de la Catedral. En todo caso, serán los prelados sucesivos los que rentabilizarán los beneficios recibidos a través de su culto y veneración. De hecho, en los documentos conservados sobre la transformación del edificio durante el siglo xvi, la consideración acerca de la necesidad de ampliar el espacio interior a consecuencia de la enorme concentración de fieles deseosos de venerar esta reliquia, será uno de los argumentos más utilizados ${ }^{27}$.

Don Nicolás de Biedma fue la cabeza visible del obispado hasta el año I383, coincidiendo con la fecha de su fallecimiento, si bien, tuvo que abandonar Jaén, trasladado a la sede de Cuenca entre $138 \mathrm{I}-\mathrm{I} 383^{28}$. Permaneció al frente de la Diócesis durante once años, en los cuales, en ocasiones, tuvo que simultanear diversos cometidos ${ }^{29}$, motivo más que suficiente, tal y como apuntara Chueca Goitia, para pensar en las dificultades que se encontraría durante la supervisión de la construcción de la

24. Sobre la veneración de las reliquias en época medieval me ha resultado de gran ayuda para la realización de este trabajo las siguientes aportaciones: FERnÁNDEZ GonzÁLez, Etelvina: «Del santo Mandilyon a la Verónica: sobre la vera icona de Cristo en la edad media», en VV.AA.: Imágenes y promotores en el arte medieval: miscelánea en homenaje a Joaquín Yarza Luaces. Barcelona, Universidad Autónoma, 2001, pp. 353-371. PÉREz GonzÁLEZ, Carlos: «El culto a las reliquias en la Edad Media: historia de una tradición pagana con continuidad en la religión cristiana», en Ruiz Sola, Aurelia \& Pérez González, Carlos: (dirs.): 16. a Jornadas de Filología Clásica de las Universidades de Castilla y León, Burgos, 2002. Burgos, Universidad, 2003, pp. 167-193.

25. Al menos así lo entendía Núñez de Sotomayor, quien lo expresa en los siguientes términos: «...la preciosísima reliquia de la Santísima Verónica, tesoro celestial con que enriqueció esta iglesia dexándola perpetuamente engrandecida». NúÑEZ DE SOTOMAYOR, Juan: op. cit. pp. 3-4.

26. Montijano ChicA, Juan: «El Santo Rostro y la Catedral de Jaén», Alto Guadalquivir, 4 (1980), pp. 24-25. GALeRA ANdreu, Pedro Antonio: «La Verónica, «objeto» de peregrinación en España», en VV.AA.: Actas del vi Congreso Español de Historia del Arte. Los Caminos y el Arte. Santiago de Compostela, 1986, Santiago de Compostela, Universidad, 1989, pp. 421-432. Aragón MorianA, Arturo: «lconografía del Santo Rostro en la Catedral giennense» Alto Guadalquivir, 17 (1993), pp. 34-35. López Pérez, Manuel: El Santo Rostro de Jaén. Córdoba, Cajasur, 1995, pp. 47-51. López Arandia, María Amparo: «Aproximación a un tratado ilustrado sobre el Santo Rostro de Jaén», Boletín del Instituto de Estudios Giennenses, 171 (1999), pp. 29-45.

27. Así se aprecia tras la lectura del pleito de la Iglesia de Jaén en la Chancillería de Granada con motivo de las obras llevadas a cabo por el Ayuntamiento en la Plaza de Santa María, o también en el Memorial de la torre del Alcotón. Véanse: LÁZARO DAMAS, María Soledad: «El memorial de la torre del Alcotón. Un interesante expediente para el estudio de la obra nueva renacentista de la catedral de Jaén», Giennium, 8 (2005), pp. 463, 483, 485, 488. GALERA Andreu, Pedro Antonio \& Ruiz Calvente, Miguel: Corpus documental para la historia del arte en Jaén. Arquitectura del siglo XVI (I). Jaén, Universidad, 2006. Documentos 179, 381-384.

28. En este período estuvo al frente de la Diócesis el prelado don Juan Rodríguez, finalmente enviado a Sigüenza, siendo ésta la causa del regreso de Biedma a la diócesis de Jaén. Rodríguez MolinA, José: op. cit. p. 46.

29. El 8 de julio de 1376 el papa Gregorio xı le encomienda las visitas del arzobispado de Sevilla y los obispados de Jaén, Córdoba, Badajoz, Plasencia, Cádiz. Idem. p. 45. 
primitiva catedral gótica ${ }^{30}$, y como consecuencia de éstas, su escaso avance por la falta de tiempo y medios.

Si por algo se ha reconocido en la historiografía la labor de Biedma ha sido por el hecho de que en las cláusulas de su testamento se recogiera su expreso deseo de convertir a la fábrica de la catedral en heredera universal de todos sus bienes ${ }^{31}$, lo cual, supondría el espaldarazo definitivo para concretar su construcción:

Item: mando et ordino, quod dentur ómnibus confraternitatibus civitatis giennensis, unicuique quinquaginta marabotini [sic] pro orationibus et honoro, quem mihi facturae sunt, cum cereis suis in die sepulturae meae. Item: mando et ordino, quod completis funeralibus meis, et solutis debitis el legatis, quae dicta sunt, omnia bona mea, in quibuscumque rebus consistant, volo quod sunt, omnia bona mea, in quibuscumque rebus consistant, volo quod sint pro fabrica et reparatione Ecclesiae giennensis, quam constituo heredem Vniversales in praedictis omnibus bonus meis et quam ego incepi aedificare ${ }^{32}$.

¿De qué forma se puede interpretar este gesto? Realmente, lejos de considerarlo como loable, detrás él se atisban ciertos intereses de reconocimiento del prestigio personal alcanzado al pasar a la historia como uno de los grandes protagonistas de tan magna obra. Pero además, el hacerlo a través de una acción de tales características, podría servir en el futuro como incentivo que impulsara este tipo de donaciones. Por otra parte, la idea de ser enterrado en el lugar más relevante del edificio, le permitiría perpetuarse en la memoria colectiva de los fieles (FIGURA 4).

Muy pocas referencias descriptivas se conservan de la primitiva catedral erigida en tiempos del obispo don Nicolás de Biedma. Especialmente interesantes son las anotaciones de los discursos del comendador Sebastián Rodrigo de Biedma y Narváez (1655), que serán contrastadas en este trabajo con las aportaciones de Martínez de Mazas (1794) en su Retrato al natural, que, aún siendo mucho más parcas, se centran especialmente en sus elementos estructurales, y en el hecho de que la nueva edificación eliminara cualquier recuerdo, por mínimo que fuera, de la antigua mezquita aljama.

30. CHueCA GoItIA, Fernando: Invariantes castizos de la arquitectura española. Madrid, Seminarios y Ediciones, 1971, p. 151.

31. «...Por el dicho Testamento mandó dar a los Conventos de Religiosos de la Trinidad y de los Frayles menores de San Francisco, y al de las Religiosas de Santa Clara todos tres de la Ciudad de laén, a cada uno Trescientos maravedís de limosna y otros Trescientos al Abad y Universidad de Priores y Beneficiados de la misma Ciudad. En una claúsula del haze memoria de la obra que començó en esta Santa Iglesia. Avía estado esta Iglesia hasta su tiempo desde que esta Ciudad de laén se ganó por el Santo Rey Don Fernando en la forma antigua que tenía de Mezquita en el de los Moros y el obispo don Nicolás se derribó en muy gran parte por don Luis de Osorio, sucesor suio, y se començó en ella el edificio de la obra nueva...» Ximena JuRADO, Martín de: op. cit., pp. 364-365. Fecha corregida por el deán Martínez de Mazas, ante el error cometido por Ximena Jurado. MarTínez de MAZAS, José: op. cit., p. 171.

32. El texto del testamento se conserva en una copia impresa (1891) transcrita y colocada en un cuadro en las galerías altas de la Catedral de Jaén. La traducción sería la siguiente: «Otrosí: mando y dispongo que se dé a todas las comunidades de la ciudad de Jaén, a cada una cincuenta maravedíes para oraciones y el funeral con sus ceras, que se me harán en el día de mi entierro, y, saldadas las cargas y los legados, que son referidos, todos mis bienes, de cualquier naturaleza que sean, es mi voluntad que sean para la fábrica y reparación de la Iglesia Giennense a la que instituyó por heredera universal de todos mis susodichos bienes y a la que yo comencé a edificar». 


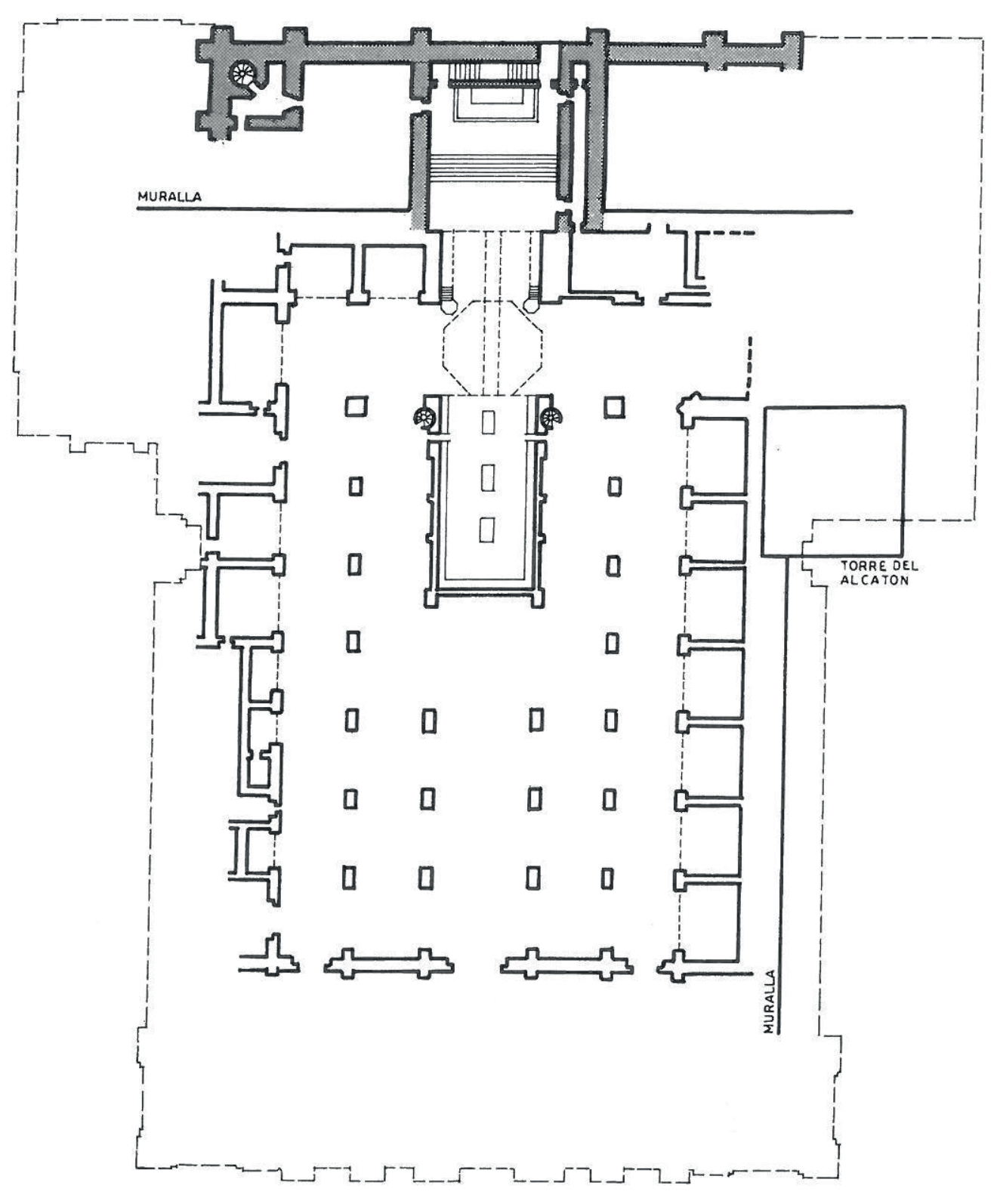

RECONSTRUCCION DE LAS
ETAPAS DE EJECUCION DE LA 1.C.

2.- CATEDRAL GOTICA

- CATEDRAL GOTICA
Uitimíos años de S.XV, y jer/6 del $x$ vio-

FIGURA 4. CATEDRAL DE JAÉN EN ÉPOCA GÓTICA

Según ORTEGA Suca (1991). 
Según las descripciones presentadas por Toral y Fernández de Peñaranda, en tiempos de Don Nicolás de Biedma:

Formose la Iglesia de cinco naves y por remate de ella una grande que llaman crucero. En la nave de en medio estaba el coro y enfrente un arco grande de más de diez varas de ancho y más de seis de fondo y muchas de alto y el crucero en medio y debajo de este arco la Capilla y altar mayor y retablo que estaba puesto y arrimado a la misma muralla de la Ciudad y en las esquinas que este arco formaba, a la parte de afuera enfrente del coro estaban dos púlpitos, y en el retablo dos escudos de armas como se han dicho33.

A tenor de lo expuesto, el tramo previo del acceso al espacio ocupado por el presbiterio correspondería al crucero. Se supone que, dada su falta de espacio, no sobresaldría de la línea de la fachada, puesto que era habitual que estos templos, al adaptarse al derruido solar de la mezquita que les precedía, mantuvieran la estructura rectangular original.

Teniendo en cuenta los datos con los que se cuenta, el coro de la primitiva catedral respondería al formato de schola cantorum ${ }^{34}$, emplazado en el eje de la nave central, pudiendo ser rodeado por los fieles por su parte delantera o trasera. De esta forma se aproximaría al modelo catedralicio hispánico (inicialmente originado en la catedral de Toledo), que a diferencia del francés (presente en las catedrales de Burgos y León) perpetúa el sistema de coro románico en la nave principal, dejando un espacio para los fieles entre éste y el altar. Además, el modelo debió evolucionar como consecuencia de la adaptación de la mezquita islámica en catedral cristiana, en cuya cabecera no había espacio suficiente como para su disposición.

En las descripciones de la primitiva construcción compiladas por Toral y Fernández de Peñaranda ${ }^{35}$ también se menciona la existencia de una capilla mayor, ubicada frente al coro, a la que se accedería a través de un arco flanqueado por sendos púlpitos. Sus dimensiones oscilaban entre las io varas de fondo ( 8,87 metros) y las 6 de ancho (5,32 metros), lo que podría hacer pensar que su espacio era infinitamente más reducido al edificado en las primeras décadas del siglo $\mathrm{Xvi}^{36}$. En su interior había un retablo ${ }^{37}$, con sus correspondientes escudos de armas. Lindaba directamente

33. «Formose la Iglesia de cinco naves y por remate de ella una grande que llaman crucero. En la nave de en medio estaba el coro y enfrente un arco grande de más de diez varas de ancho y más de séis de fondo y muchas de alto y el crucero en medio y debajo de este arco la Capilla y altar mayor y retablo que estaba puesto y arrimado a la misma muralla de la Ciudad y en las esquinas que este arco formaba, a la parte de afuera enfrente del coro estaban dos púlpitos, y el en el retablo dos escudos de armas como se han dicho». TORAL y FERNÁNDEZ DE PEÑARANDA, Enrique: «El comendador don Sebastián Rodrigo de Biedma y Narváez y su descripción de las obras de la catedral nueva de Jaén», Boletín del Instituto de Estudios Giennenses, 102 (1980), pp. 60-61.

34. Navascués Palacio, Pedro: «Los coros catedralicios españoles», en Yzquierdo Perrín, Ramón (ed.): Los coros de catedrales y monasterios: arte y liturgia. A Coruña, Fundación P. Barrié de la Maza, 2001, pp. 32-35.

35. Toral y Fernández de Peñaranda, Enrique: op. cit., p. 61.

36. Referente a la capilla mayor labrada en tiempos de don Alonso Suárez, apunta Martínez de Mazas lo siguiente: «...era cuadrada y cerrada, de 48 pies de largo y 38 de ancho, sin que le acompañase otro edificio por los costados ni por detrás, porque el muro principal de la iglesia estaba separado». MARTínEZ DE MAZAS, José: op. cit., p. 185.

37. De Ulierte VÁzquez, M. ${ }^{a}$ Luz: El retablo en Jaén (1580-1800). Jaén, Ayuntamiento, 1986, pp. 82-83; $296-298$. JódAr MenA, Manuel: «El derecho de patronazgo y la capilla mayor de la Catedral de Jaén: aportaciones documentales de la casa de Santisteban del Puerto», en Ramalló Asensio, Germán (coord.): Actas del Congreso: El 
con la muralla, siendo éste el obstáculo principal que ocasionaba esas condiciones de estrechez, oscuridad y humedad que acrecentarían con el tiempo su deterioro, haciéndonos creer esto que, en cierta manera, el detonante de su transformación sería su grave peligro de derrumbe.

Además, según apunta Martínez de Mazas, existía un claustro, de forma contraria a la tradición, emplazado en el flanco norte ${ }^{38}$, ocupando parte del espacio de la posterior lonja. Probablemente su ubicación coincidiría con el lugar donde se hallaba el sahn de la otrora mezquita, disponiendo de una estructura irregular, condicionada por la forma del patio de la antigua aljama. Se desconoce en qué momento desaparecería. Galera Andreu ha apuntado la posibilidad de que perdurara parcialmente hasta el siglo XVII ${ }^{39}$, cuando definitivamente fueron eliminados la mayor parte de los resquicios de la calificada en las fuentes como «obra antigua».

De «las otras dependencias necesarias» que cita Martínez de Mazas se carece de información alguna. Además, a pesar de que mencione la existencia de documentación escrita relativa a las reformas realizadas en el edificio durante esta etapa ${ }^{40}$, nada se sabe al respecto, ni tampoco han sido citadas en algún otro trabajo, con lo cual, estas aportaciones son poco probable que puedan enriquecer el conocimiento sobre la primitiva construcción catedralicia.

Tampoco es posible añadir datos nuevos sobre los maestros que intervinieron en la primitiva fábrica gótica de finales del siglo xıv. Posiblemente algunos procederían de otros reinos, incluso y aunque de forma más remota, pudieron haber participado algunos mudéjares, bastante instruidos en determinados oficios artísticos, que, lógicamente, habrían dejado elementos materiales con una marcada impronta, tal y como ocurrió, por ejemplo, en la catedral de Toledo. La cuestión de los artífices fue recogida por Martínez de Mazas en su Retrato al natural, incidiendo en las dificultades para encontrar artistas que, trabajando en el estilo gótico, llegaran a realizar edificaciones semejantes a las producidas en este tiempo en Castilla ${ }^{41}$, considerada, en este caso, como paradigma de la arquitectura de la época.

La precariedad de los recursos económicos de la catedral gótica a finales del siglo xIV y durante la primera mitad del siglo xv se arrastró a lo largo de varias centurias. Esto no empañó la intensa labor de promoción acometida por los obispos de la Diócesis. Un ejemplo de ello lo vemos en la figura de don Gonzalo de Estúñiga (I423-I456), quien consiguió que el papa Calixto Iı promulgara una bula, finalmente

Comportamiento de las Catedrales españolas. Del Barroco a los Historicismos, Murcia, 2002. Murcia, Universidad, 2003, pp. 473-482.

38. Así lo han destacado, entre otros, Ulierte Vázquez o Galera Andreu al referirse a las limitaciones impuestas tanto por la muralla como por las Casas del Cabildo. Véanse: De UlierTe VÁzQuez, María Luz: op. cit., p. 72. GALERA Andreu, Pedro Antonio: Las Catedrales de Vandelvira. Úbeda, El Olivo, 2006, p. 6.

39. Galera Andreu, Pedro Antonio: op. cit., p. 3.

40. Martínez de Mazas, José: op. cit., p. 170.

41. «...Dos siglos antes se estubo meditando un edificio que fuese digno de una Catedral tan ilustre, y se aplicaron las manos a ella desde el famoso Obispo Don Nicolás de Biedma; pero no había entonces Maestros que entendiesen de dar buenas formas, solidez y distribución a los Edificios públicos ni privados, a lo menos no los había en esta tierra, como se hecha de ver en quantos perseveran del siglo XIV y XV. Ya nos contentáramos con que se huviera fabricado una buena obra de estilo gótico como las que hay en Castilla; pero tampoco había caudales para ello, ni lo permitían las frecuentes entradas de los moros de Granada». Idem. pp. 168-169. 
concedida con fecha I4 de febrero de I458, con la que se otorgarían indulgencias a los que visitasen y colaboraran económicamente con las dos catedrales del obispado Baeza-Jaén «ad reparationem et restaurationem dictarum ecclesiarum» ${ }^{42}$. Lógicamente, su relevancia hemos de entenderla en función de la difícil coyuntura en la que se encontraba la Diócesis, limitada por la falta de medios y determinada por su problemática condición de tierra fronteriza. En cualquier caso, no se ha de considerar como un hecho aislado, dado que a lo largo de la historia otras construcciones catedralicias, tales como las de Segovia, Toledo, o el Burgo de Osma, fueron impulsadas por la concesión de privilegios de parecida naturaleza.

\section{LA CRÓNICA DEL CONDESTABLE MIGUEL LUCAS DE IRANZO (1458-1471)}

La catedral de Jaén aparece citada en la crónica del Condestable Miguel Lucas de Iranzo a través de la narración de varios acontecimientos de la vida de su protagonista ${ }^{43}$. Su cronista, por medio de breves pinceladas descriptivas, nos aproxima al conocimiento del estado en el que se encontraba la seo giennense en una época, durante la prelatura de don Alonso Vázquez de Acuña (I457-I474), en la que carecemos de otras fuentes escritas que nos aporten información al respecto, de ahí la verdadera relevancia de su análisis ${ }^{44}$ (FIGURA 5).

En tiempos del Condestable las plazas surgidas en torno a los templos parroquiales de la ciudad de Jaén se convierten en auténticos espacios de representación:

Y como se puso el sol, fueron fechos muy grandes fuegos, e en todas las plaças e a las puertas de las iglesias de la dicha çibdad; en las quales asavan muchas aves e cabritos, e casi los toçinos enteros; e comían e bevían todos lo que querían. Espeçialmente, en la plaça de Santa María45.

Entre ellas, lógicamente, el lugar más emblemático era aquel en el que se encontraba el templo mayor, la Plaza de Santa María, convirtiéndose en este momento, a través de las distintas transformaciones urbanísticas, en un enclave en el que confluían los poderes civil y religioso, representados y enfrentados, a través de una serie de obras arquitectónicas: el primero, en las casas del cabildo o las residencias

42. Sobre la Bula, que se conserva en el Archivo Secreto Vaticano nos ofrece información MARTínEz RojAS, Francisco Juan: «Novam Ecclesiam egregia structura facere. Documentos episcopales y pontificios para la construcción de la Catedral de Jaén I (Siglos XV-XvI)», Giennium, 2 (1999), pp. 342-343.

43. Las referencias que aparecen en la Crónica sobre la Catedral de Jaén aparecen entre los acontecimientos narrados entre los años 1461-1468. Cuevas MatA, Juan, Del Arco MoyA, José \& Del Arco Moya, Juan: Relación de los Hechos del muy magnífico e más virtuoso, el Señor don Miguel Lucas, muy digno Condestable de Castilla. Jaén, Universidad y Ayuntamiento de Jaén, 2001. A partir de ahora me referiré a ella como: Crónica del Condestable.

44. Morales Gila, Paula: «La catedral de Jaén en la época del condestable don Miguel Lucas de Iranzo», en SÁNCHez López, Juan Antonio \& Coloma MARTín, Isidoro (coords.): Correspondencia e integración de las artes: $14 .^{\circ}$ Congreso Nacional de Historia del Arte. Vol. I Madrid, Ministerio de Educación, Dirección de Cooperación y Comunicación Cultural, 2003, pp. 337-344.

45. Crónica del Condestable, 1465, p. 212. 


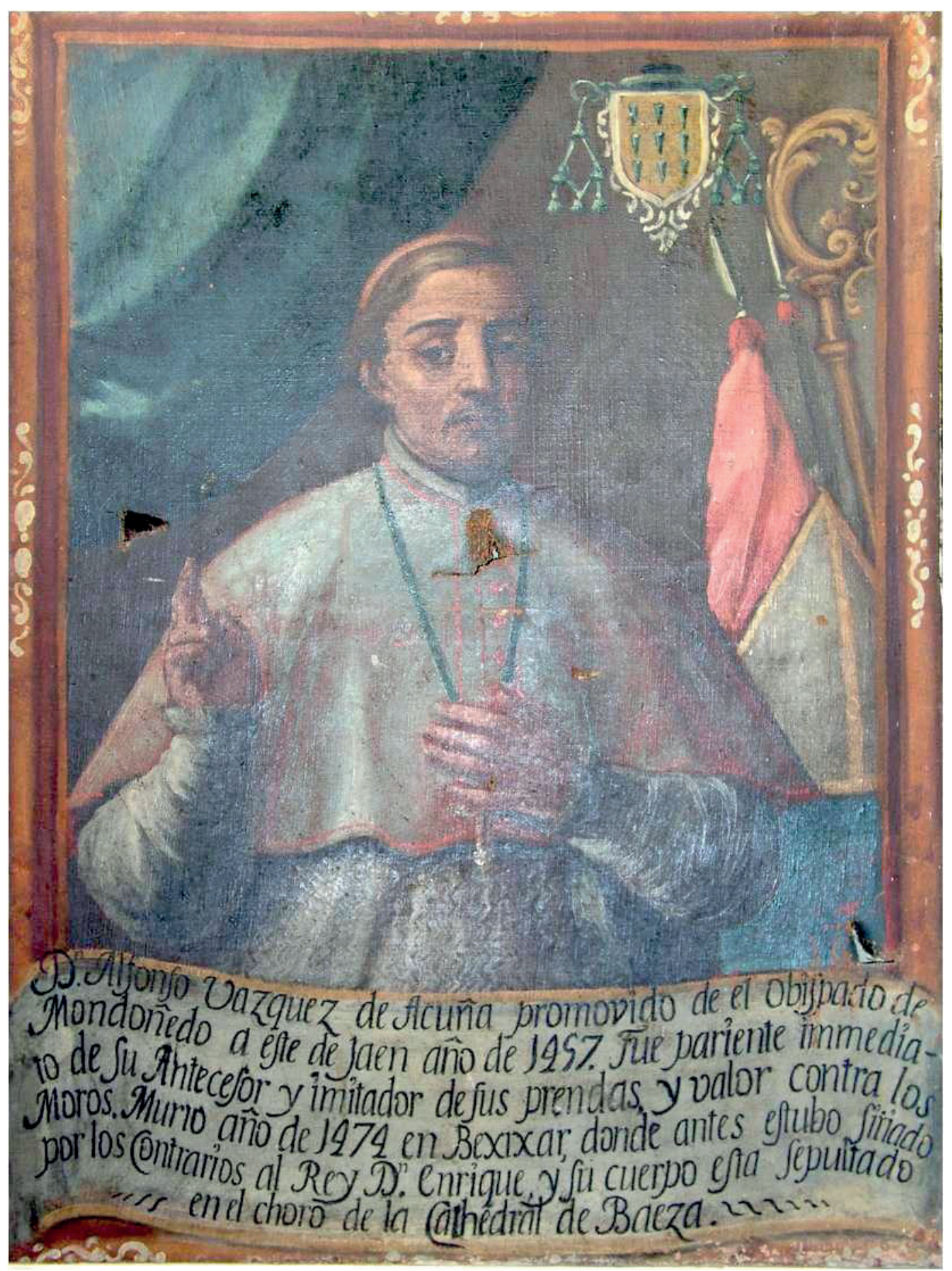

FIGURA 5. DON ALONSO VÁZQUEZ DE ACUÑA

Archivo Histórico Diocesano de Jaén. 
de los linajes más destacados de la época, y el segundo, a través de la catedral o el palacio episcopal.

Es éste un momento decisivo para la historia constructiva de la catedral, dado que el flanco sur, tradicionalmente limitado por el recinto murario y por la disposición de las casas del cabildo, comenzará a ser transformado ${ }^{46}$, convirtiéndose estos cambios en una futura válvula de escape para el trazado de la renovada edificación a lo largo de la centuria siguiente. Por otra parte, se inicia un proceso de revitalización de los espacios adyacentes al templo mayor, con la posibilidad, una vez que fueran derruidas las murallas medievales, de generar nuevos ejes que conectaran las distintas collaciones y arrabales de la ciudad ${ }^{47}$.

Respecto a las aportaciones concernientes a la estructura de la catedral que se pueden destacar tras la lectura de la Crónica, es necesario aludir a las referencias expresas a sus accesos (puertas y portadas), con datos que aportan información no sólo sobre sus nombres, sino también sobre su emplazamiento concreto. Así en los Hechos del Condestable se cita preferentemente la Puerta del Perdón, siendo ésta, tal y como se comenta en el pleito entre los cabildos municipal y catedralicio del año I5I6, la portada principal de la Catedral gótica ${ }^{48}$, motivo más que suficiente para ser citada y utilizada en un mayor número de ocasiones que el resto de las entradas del templo.

Según el plano publicado por Chueca Goitia, elaborado por Juan de Aranda en función del estado en el que se encontraba la catedral con anterioridad a las transformaciones acometidas en el siglo $\mathrm{XVII}^{49}$, se hallaría localizada a los pies de la nave central, presentando un tamaño mayor al de las otras dos portadas de esta fachada, situadas, respectivamente en las naves colaterales más cercanas a los muros del evangelio y de la epístola. A todas ellas se accedía a través de la Plaza de Santa María. La estructura de triple portada se mantuvo en la renovada fachada materializada por Eufrasio López de Rojas, pudiendo así ser considerada como uno de los caracteres de la primitiva construcción medieval perpetuados en la construcción catedralicia. Martínez de Mazas alude en su obra a la antigua portada principal en los siguientes términos:

La fachada principal de la plaza de Santa María es obra de mayor grandeza y extensión... Adornan a este cuerpo ocho medias columnas, las quatro del medio pareadas, que sirven de división a las tres puertas principales, que dan entrada a las tres naves

46. «Notorio es que la plaça de Santa María, do acostunbravan jugar a las cañas, estava muy mala e muy áspera de munchas peñas e piedras; en tal manera que munchos cavallos e cavalleros caían e se lisiavan allí. La qual mandó allanar e despedregar de una parte e de otra. E por la más ensanchar, mandó derribar unas paredes que estavan delante de las casas de Cabildo, e arrancar unos árboles que estavan allí; por manera que está agora la más llana e la más gentil plaça del mundo». Crónica del Condestable, 1463, p. 100.

47. Otrosí mando desfazer e quitar unas carneçerías que estavan saliendo por la puerta de Santa María de la dicha çibdad; e mandolo todo allanar e linpiar, porque estavan muy mal e ocupavan la entrada e salida». Crónica del Condestable, 1463, p. 101.

48. «...consintieren que el dicho edificio e agua fuese por (roto) pequeña de los (roto) e de la puerta del perdón, que es la principal de la iglesia». Galera Andreu, Pedro Antonio \& Ruiz Calvente, Miguel: op. cit., p. 290.

49. Chueca Goitia, Fernando: op. cit., p. 153. Aportaciones que pueden contrastarse comparando la planta que conserva el ideario vandelviriano. Véase: Del ArCo MoyA, Juan: «La planta de la Catedral de Jaén de Juan de Aranda», Códice, 20 (2007), pp. 37-44. 


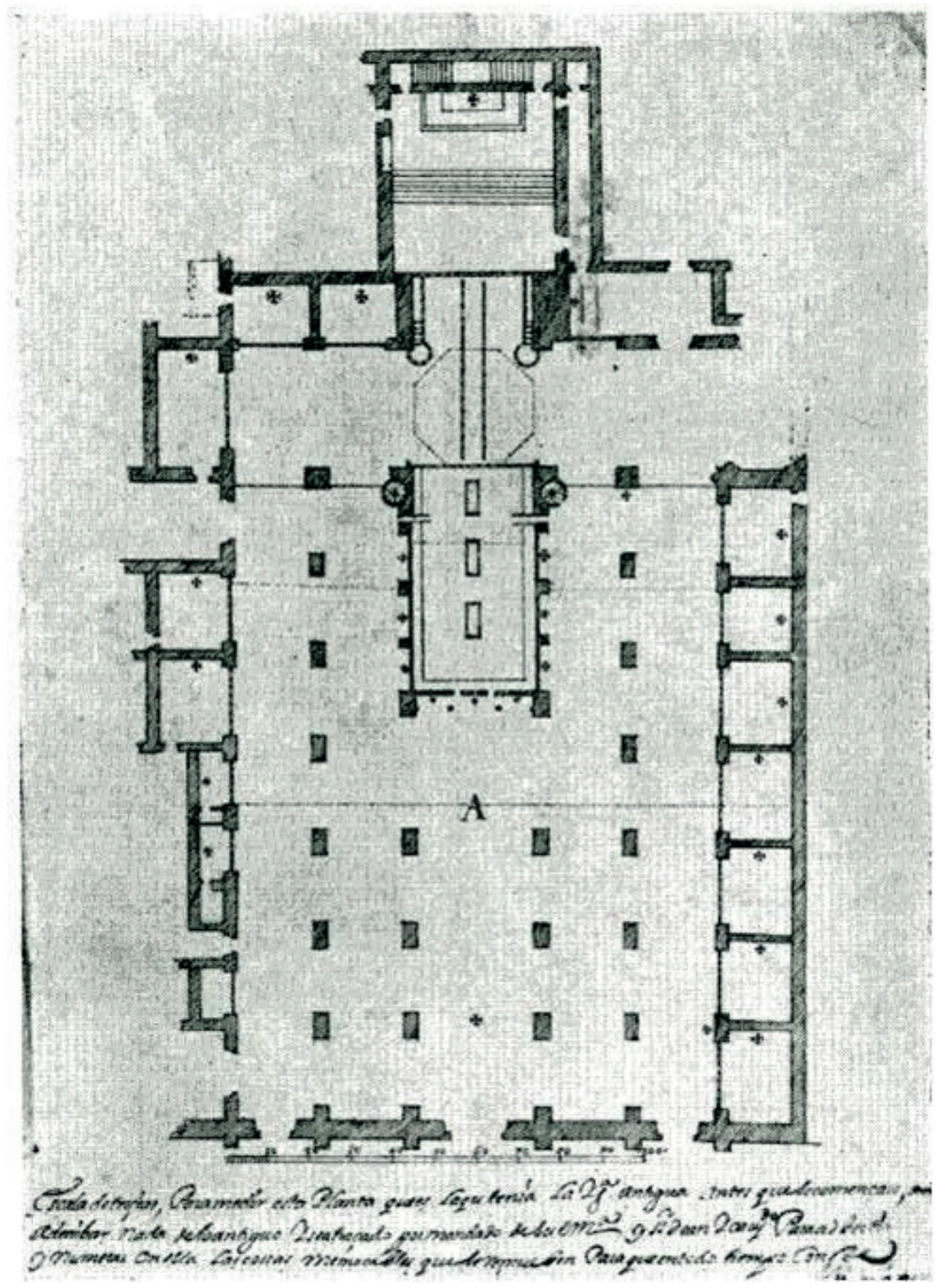

FIGURA 6. PLANTA DE LA PRIMITIVA FÁBRICA GÓTICA DE LA CATEDRAL DE JAÉN CHUECA (1971), p. 153 
de la Iglesia. La del medio, que se llamó en lo antiguo del Perdón, como en otras Catedrales, es más capaz y más alta que las otras» ${ }^{50}$ (FIGURA 6).

Nieto Cumplido, al referirse a la de la Catedral de Córdoba, compara la Puerta del Perdón con la del atrio de las basílicas romanas, convirtiéndose en un acceso solemne y protocolario, especialmente reservado a los obispos o a los miembros del Concejo durante funerales o celebraciones matrimoniales de personajes relevantes, visitas reales o incluso ritos procesionales ${ }^{\mathrm{II}}$. De la misma manera ocurrió en el caso de Jaén, a tenor de la lectura de los acontecimientos más destacados en la Crónica de Miguel Lucas de Iranzo.

Se supone, a raíz de las aportaciones los Hechos del Condestable, que tanto las puertas de la fachada principal como las del trascoro se abrirían en momentos puntuales, siendo ésta la manera por la cual el Condestable y la Condesa, los miembros de «su corte» y los personajes más destacados de la ciudad accederían al crucero y abandonarían el templo mayor para dirigirse a su casa-palacio:

...E así llegados a la iglesia mayor, en la manera e orden susodicha, entraron todos por la
Puerta del Perdón e por las puertas del coro, e salieron al crucero, donde estava puesta
la tumba. (...) E acabado esto la orden que se tobo en volver... por la mema orden que
levaron a la ida, por la nave que viene del Sagrario e junto con el coro; e en pos del to-
dos se entraron en la nave mayor; e por la mesma parte que vino se bolvió; e salieron
todos por orden, por la puerta del Perdón, por do entraron. E así vinieron a Palaçio ${ }^{52}$.

La única referencia espacial que aporta la Crónica respecto a la citada portada hace alusión a su ubicación, frente al altar de Nuestra Señora de la Consolación, que tal y como recogen los estatutos catedralicios de $147^{53}$, se encontraba alineada en el muro del trascoro: «Y su merced oyó misa con el dicho Juliano; e su muger en el altar de Santa María de la Consolación que está de frente a la puerta de la dicha iglesia» ${ }^{54}$.

$\mathrm{Al}$ revelar el cronista que la llamada Puerta del Sagrario ${ }^{55}$ servía para dar nombre a una de las naves del templo ${ }^{56}$, se piensa debiera tratarse de otra de las puertas de la fachada principal, concretamente la correspondiente a la nave del evangelio. Esta puerta aún mantiene esta denominación en el año $1510^{57}$.

50. Martínez de Mazas, José: op. cit., pp. 209-210.

51. Nieto Cumplido, Manuel: La Catedral de Córdoba. Córdoba, Obra social y cultural Cajasur, 1998, p. 604.

52. Crónica del Condestable, 1464, pp. 200, 202.

53. Rodríguez Molina, José: «Estatutos de la Catedral de Jaén: recopilación de 1478», Boletín del Instituto de Estudios Giennenses, 85-86 (1975), p. 50.

54. Crónica del Condestable, 1466, pág. 250.

55. También citada por Lázaro Damas, aunque sin precisar nada a propósito de su emplazamiento. Véase: LÁzARO DAMAS, María Soledad: «La Catedral medieval y la obra nueva tardogótica. Los proyectos de los obispos Osorio y Fuente del Sauce», en Del Arco Moya, Juan (coord.): Andrés de Vandelvira. Vida y obra de un arquitecto del Renacimiento. Jaén, Ayuntamiento, 2006, p. 78.

56. «E salía la dicha proçesión por la nave del Sagrario, e ivan fasta la puerta de la iglesia que está en la dicha nave; e bolvía por la nave de la capilla del Señor Sant Lucas». Crónica del Condestable, 1464, pág. 149.

57. «El pilar se faga e comience desde la esquina del (...), entrando por la puerta de la iglesia mayor, que está en derecho del Sagrario...» Galera Andreu, Pedro Antonio \& Ruiz Calvente, Miguel: op. cit., p. 298. 
Otro de los accesos citados en la Crónica es la llamada Puerta de los Capellanes ${ }^{58}$. A pesar del posible equívoco que pudiera suponer el hecho de que así se aluda a una de las capillas del templo, no se cree que el texto se refiera a su puerta, sino a que la nave donde se encontraba, probablemente la de la epístola, tuviera una portada que recibiría el mismo nombre.

Igualmente en los Hechos del Condestable se menciona la llamada Puerta del Álamo, sobre la cual, sólo existe una parca reseña:

La misa acabada, el dicho señor condestable salió de la iglesia por la puerta del Álamo e fuese a su posada sin mirar a los otros que estavan puestos a la puerta de la posada del obispo ${ }^{59}$.

Sin cualquier otra referencia espacial, las únicas consideraciones que se podrían realizar no pasarían de ser meras hipótesis. Lázaro Damas piensa que es una de las puertas laterales que integraban la fachada principal ${ }^{60}$. Mientras que Morales Gila la sitúa en el muro del evangelio, en la esquina de la actual calle Campanas ${ }^{61}$, apoyándose en las siguientes afirmaciones de Martínez de Mazas:

Por el otro lado (se refiere al flanco norte) había dos puertas que salían a la calle, una de ellas contigua a una capilla pequeña, que pudo ser la de Santa Lucía y la otra a varios lugares que allí se notan que serían los comunes, y el pequeño huerto o la entrada a la torre y habitación de campaneros ${ }^{62}$.

Si la Puerta del Álamo fuera uno de los dos accesos citados por Martínez de Mazas en el flanco norte, el segundo bien pudiera ser la puerta Bermeja, que aunque no aparezca en la Crónica del Condestable, sí que es aludida en la documentación de comienzos del siglo $\mathrm{xvI}^{63}$, y así se hace eco de ella la propia historiografía ${ }^{64}$.

El flanco sur, condicionado por la estructura de la muralla, carecía de acceso alguno. Lo único que había era un viejo postigo que pensamos se emplearía para la entrada y salida de materiales durante las obras realizadas en el interior del edificio, pero que, coyunturalmente, sería la única manera de llegar a los arrabales de la ciudad. No obstante, a mediados del siglo xvi, ya se consideraba una necesidad abrir una portada por el lateral del mediodía, tal y como ocurría en la mayor parte de las catedrales españolas:

58. «E así las levó a la iglesia catedral de Santa María, donde a las puertas del capellán mayor del dicho señor condestable, de muy ricas vestimentas ornados estava. $Y$ dadas las acostumbradas bendiçiones, los novios a sus mujeres de braço tomando, entraron por la iglesia fasta una capilla que es del dicho capellán mayor la misa muy solemne e devotamente se dixo». Crónica del Condestable, 1463, p. 113.

59. Crónica del Condestable, 1463, p. 107.

6o. LÁzaro Damas, María Soledad: op. cit., p. 78.

61. Morales Gila, Paula: op. cit., p. 344.

62. Martínez de MazAs, José: op. cit., pp. 189-190.

63. Galera Andreu, Pedro Antonio \& Ruiz Calvente, Miguel: op. cit., pp. 290, 298.

64. Lázaro Damas se refiere a ella como una de las tres puertas de la fachada principal. En cambio, Galera Andreu, pensamos de forma más acertada, la vincula con uno de los posibles accesos al claustro, situado en este flanco norte. Véanse: Galera Andreu, Pedro Antonio: op. cit., pág. 6; LázAro Damas, María Soledad: op. cit., p. 78. 
...ninguna iglesia catedral en este rei/no está sin puerta del mediodia si no es la dicha iglesia mayor/ haziéndose la dicha puerta se çierra el postigo viejo de la dicha/ obra por donde suelen entrar y salir de los dichos arrabales/a esta çibdad ${ }^{65}$.

También en el exterior de la catedral se ha de destacar la existencia de la referida en los Hechos del Condestable como «torre del relox». En el año I457 era la única con la que contaba el templo mayor ${ }^{66}$. Se piensa que rivalizaría en altura con los cercanos baluartes del núcleo defensivo, precisamente por eso considero que pudo ser codiciada por los rivales de Miguel Lucas, entre los que se encontraba el obispo don Alonso Vázquez de Acuña, para ser utilizada como lugar de refugio y presidio temporal ${ }^{67}$.

Al respecto de su ubicación, Lázaro Damas la sitúa cerca de la que considera uno de los tres accesos de la fachada principal, la antes citada puerta Bermeja ${ }^{68}$. La historiografía, probablemente como consecuencia de las interpretaciones de las noticias recogidas por Martínez de Mazas, ha vinculado su existencia a la del controvertido espacio del claustro ${ }^{69}$.

En cualquier caso, también se disponen datos, procedentes de los Estatutos catedralicios (I478) compilados por Rodríguez Molina, que resultan un tanto contradictorios a este respecto ${ }^{70}$, dado que su vinculación espacial con las casas del cabildo y la claustra, podrían hacer pensar que su emplazamiento se hallara en línea con la nave de la epístola, en el ángulo formado por el flanco sur de la plaza de Santa María, en el cruce entre la calle Almenas y la Carrera de Jesús. Particularmente, me inclino por considerar que se encontraba situada en el extremo opuesto, en el ángulo que formaba la Plaza de Santa María y la calle Campanas. El libro de visitas de la catedral de Jaén del año I539, al describir pormenorizadamente la estructura de las capillas del templo, así parece corroborarlo ${ }^{71}$. Además todo apunta a que esta torre equilibraría la presencia de la existente en el flanco opuesto, que ya estaba proyectada

65. Archivo Histórico Diocesano de Jaén (AHDJ), Memorial de la Torre del Alcotón. Legajo 25. Fol. 9v.

66. «El anciano pertiguero Juan de León, se pasó toda la tarde del 3 de Agosto de 1457 avisando a los señores del Cabildo de Iglesia; ya a unos en el Torreón de los Abades, ya a otros en las Casas del Deanato; a estos en la Torre del Obispo, y a aquellos en los estrechos callejones, próximos a las murallas, donde tenían sus viviendas. Además, la campana del Cabildo, dio, desde la torre única del templo, los toques de aviso y citación mandados por los Estatutos». Cazabán Laguna, Alfredo: «De cómo entró en Jaén el Sr. D. Alonso Vázquez de Acuña», Don Lope de Sosa, 3, 1913, p. 258.

67. «...como el señor condestable oyó misa e se vino a su posada, luego los del obispo tomaron la iglesia mayor e atrancaron muy bien las puertas, e tomaron lo de arriba, e la torre del relox, e pusieron gente en ella». Crónica del Condestable, 1463, pp. 108-109.

68. LÁzaro Damas, María Soledad: «La Catedral...», p. 78.

69. Galera Andreu, Pedro Antonio: La Catedral..., p. 4; Galera Andreu, Pedro Antonio: Las catedrales..., p. 6.

70. «Si fuera procesión que sean obligados de venir a ella a lo menos ante la procesión entre la segunda estaçión que se faze desde la puerta de la Torre del Reloj, que es cerca del Consistorio en la claustra fasta la Capilla de Sant Juan». Rodríguez Molina, José: «Estatutos de...», pp. 83-84.

71. Al referirse a la capilla de Santa Ana, emplazada en la nave del evangelio, nos aporta los siguientes datos: «Junto a la dicha capilla de don Luis de Torres/ está la capilla de Sancta Ana, sobre la qual/ está fundada la torre de las campanas». LÁZARO DAmAS, María Soledad: «La catedral de Jaén según el libro de visitas de 1539», Boletín del Instituto de Estudios Giennenses, 170 (1998), p. 99. 
a finales del siglo $\mathrm{XVI}^{72}$, aunque su materialización no se produjera hasta que Eufrasio López de Rojas no completara la estructura de la actual fachada principal.

A pesar de que Gómez Moreno vincule la «torre del reloj» con el primitivo alminar, el hecho de que en 1513 se aluda a los pretiles y almenas que la coronaban ${ }^{73}$, además de las acertadas reflexiones de Galera Andreu respecto a su emplazamiento, justo en un ángulo del recinto defensivo de Jaén ${ }^{74}$, hacen decantarme por la hipótesis del reaprovechamiento de alguna de las torres del primitivo recinto defensivo ${ }^{75}$. Si así se corroborara, su apariencia debiera corresponderse con las de cualquier baluarte defensivo. Es por esto que no sorprenden los comentarios de Martínez de Mazas a propósito de su robustez y fortaleza estructural ${ }^{7}$. Por otra parte, y como era frecuente en los alrededores de las puertas y torres de las ciudades, la presencia de una intensa actividad comercial, igualmente es constatada en las noticias aportadas en el Retrato al natural de la ciudad de Jaén ${ }^{77}$.

La función que en estos momentos desempeñaba no debió de ir más allá de la de convocar a los fieles. A raíz de la información proporcionada por Rodríguez Molina estaría conformada, al menos, por dos campanas con tamaños diferenciados ${ }^{78}$, utilizadas de forma ritual para el llamamiento a los creyentes a que participaran en las distintas actividades litúrgicas, pero también, para convocar a los miembros del cabildo catedralicio ${ }^{79}$.

Al margen de su apariencia, como ya se ha comentado anteriormente, más próxima a la de una torre de un recinto defensivo que a la de un alminar reaprovechado como torre campanario, he de añadir que en su interior, y según los datos de Martínez de Mazas, existía una habitación destinada a los campaneros ${ }^{80}$. Además la documentación escrita informa de las reparaciones efectuadas por el maestro Diego Martínez (1513), artífice del chapitel que la coronaba ${ }^{81}$, originalmente encargado al maestro Pedro Guerra ${ }^{82}$. Fue finalmente derribada a mediados del siglo

72. «Todavía para dar más hermosura a la fachada de la catedral faltaba que se cortasen las casas del ayuntamiento que llegaban a tocar con la torre del mediodía. Ya anteriormente se habían concedido cortar otra parte de las dichas casas para alargar la Iglesia y edificar la torre de aquel lado». MARTíneZ DE MAZAS, José: op. cit., p. 194.

73. Gómez Moreno, Manuel: «La sillería del coro de la Catedral de Jaén», Arte Español, 3 (1941), p. 3.

74. En un Privilegio Real de 1432 se recoge la siguiente descripción: «En un canto de la ciudad, y por tal guisa que el Adarve e torres de la cerca están encorporadas en ella, las quales torres se mandan por la dicha iglesia e las tienen el obispo e canónigos de ella. E que so aquellas torres estaba una de las puertas de esa Cibdat, la qual dicha Iglesia diz que es asaz fuerte de todas partes contra la dicha cibdat». Citado por: Galera Andreu, Pedro Antonio: La Catedral..., p. 4.

75. Así lo ha pensado también Lázaro Damas. Véase: LÁZARO DAMAS, María Soledad: «La Catedral medieval...», p. 78.

76. Martínez de Mazas, José: op. cit., p. 182.

77. Idem., p. 194

78. «A las primeras Viésperas fecha la señal acostumbrada por la campanilla pequeña de la torre tenga luego el campanero una campana de las dos más pequeñas que están en la torre... Primeramente, a las Viésperas primeras que fagan señal e luego el campanero escomençe a tañer la más pequeña campana que oviere en la torre e luego sy compañera... espere la señal del coro para tañer a entrada e fecha la señal comience a tañer el campanero una de las campanas menores de la torre e luego la otra su compañero». RodRíGUEZ MolinA, José: «Estatutos de ...», pp. 46-47.

79. Cazabán Laguna, Alfredo: op. cit., p. 258

80. Martínez de Mazas, José: op. cit., p. 182.

81. Así lo destaca Gómez Moreno en función de las noticias recogidas de los libros de fábrica que hoy se encuentran en paradero desconocido. Gómez Moreno, Manuel: op. cit., p. 4.

82. «Pedro Guerra, cantero, tiene odio al dicho obispo (se refiere a don Alonso Suárez de la Fuente del Sauce) 
xvill, momento en el cual ya se distinguía la torre nueva, construida posiblemente en la centuria anterior, de la vieja ${ }^{83}$.

De los apuntes descriptivos del interior del conjunto catedralicio aportados por los Hechos del Condestable, sobresalen, por su carácter eminentemente representativo, dos espacios: el crucero y el coro. El primero de ellos es un lugar especialmente reservado para la celebración de acontecimientos distinguidos, de ahí que sea donde se encuentre emplazado el estrado ${ }^{84}$ desde el que el Condestable y la Condesa, acompañados en ocasiones por personas destacadas, participaban en las más variadas celebraciones litúrgicas ${ }^{85}$ : esponsales, funerales...

Las notas encontradas sobre el coro, permiten reforzar la hipótesis anteriormente planteada sobre su emplazamiento en la nave central, a la manera de schola cantorum $^{86}$, aprovechando el espacio existente entre el altar mayor y el crucero ${ }^{87}$. Además poseía varios accesos que permitían su comunicación con las naves laterales $^{88}$, citándose sus puertas (las más pequeñas), y las que formaban parte del trascoro, donde tradicionalmente había dispuestos distintos altares, que aún aparecen mencionados en los libros de las visitas del año $1539^{89}$. Cazabán Laguna, parafraseando al padre Francisco de Bilches ${ }^{9 \circ}$ (I653), publica unos breves apuntes descriptivos, de la época del prelado don Alonso Vázquez de Acuña (I457), confirmando lo mencionado acerca de sus accesos, e incidiendo en los problemas de iluminación del templo, anteriormente mencionados:

....levaron al coro a Gonzalo Cano. Era el coro pequeño, obscuro como toda la Iglesia, de techo bajo, y tenía las dos puertecillas de entrada por la espalda, a más de la que, abierta al ancho de la nave, daba al Presbiterio ${ }^{91}$.

Curiosamente, a pesar de que, según la tradición, este espacio haya estado reservado a hombres consagrados a la vida religiosa (diáconos, presbíteros, obispos...), en los Hechos del Condestable se revela cómo, en ocasiones, es utilizado por el Condestable, la Condesa, regidores, alcaldes o jurados de la ciudad ${ }^{22}$. Se piensa que éste

porque al tiempo que se hazía e labrava el campanario e chapitel de la dicha iglesia mayor de Santa María le mandó que no entendiese en la dicha obra e se la hizo quitar». Galera Andreu, Pedro Antonio \& Ruiz Calvente, Miguel: Corpus documental..., p. 300.

83. Galera Andreu, Pedro Antonio: Las Catedrales..., p. 6.

84. Crónica del Condestable, 1461, p. 41.

85. Las celebraciones más destacadas acontecidas en el crucero de la Catedral en tiempos del Condestable han sido compendiadas en: Morales Gila, Paula: op. cit., p. 339.

86. Navascués Palacio, Pedro: op. cit., pp. 32-35.

87. Crónica del Condestable, 1461, p. 41

88. Tal y como también ha reparado Morales Gila. Véase: Morales GILA, Paula: op. cit., p. 340.

89. Concretamente se mencionan: el altar de los Ángeles, el altar de San Sebastián, el altar de Nuestra Señora de la Consolación, el altar de Santa Marta y el de San Gregorio. LÁZARo Damas, María Soledad: «La Catedral de...», p. 119 .

90. De BILCHES, Francisco: Santos y santuarios del Obispado de Jaén y Baeza. Jaén, Impresión Domingo García Morras, 1653

91. Cazabán laguna, Alfredo: op. cit., p. 259.

92. Crónica del Condestable, 1464, p. 202. Morales Gila alude al acceso de los laicos al coro a partir de la Edad Media, reparando, en el caso de Jaén, en el paso de personas notable entre las que se encontraban los Condestables de Castilla. Morales GiLA, Paula: op. cit., p. 341. 
pudo ser motivo más que suficiente para que, tal y como se recoge en el Sínodo de $1492^{93}$, se prohíba expresamente a todo laico «cualquier condiçión que sea» profanar espacio tan sagrado.

La sacristía también es mencionada en la Crónica del Condestable como el espacio empleado por los celebrantes para cambiarse antes y después de la celebración, aludiéndose a ella con el término: «vistario» ${ }^{94}$, sin aportarse ninguna referencia más a propósito de su emplazamiento, su tamaño, su estructura o sus elementos ornamentales. A través del memorial de la torre del Alcotón (1540) se sabe que la primitiva sacristía catedralicia, se hallaba incrustada en el flanco sur, aprovechando parte de las estructuras del recinto defensivo ${ }^{95}$. Probablemente de la lectura de este documento el deán Martínez de Mazas extrajo como conclusión el pequeño tamaño y los graves riesgos de derrumbe que presentaba ${ }^{96}$.

Las referencias encontradas en los Hechos del Condestable respecto a la capilla mayor hacen pensar que ésta se mantiene tal cual había sido construida en tiempos de don Nicolás de Biedma a finales del siglo xıv, formada por un espacio rectangular de reducidas dimensiones, a causa de las limitaciones impuestas por el recinto defensivo, y al que se accedía a través de un gran arco, tal y como se extrae del siguiente fragmento: «agora es arco principal por do entran a la capilla mayor y hincase de rodillas en las gradas ${ }^{97}$.

Finalmente me referiré a la información recogida en los Hechos del Condestable sobre algunas de las capillas y altares que componían la estructura del templo catedralicio. Ambos se describen correctamente guarnecidos, sin que aparentemente existiera en ellos uno de los problemas denunciados en el Sínodo de I492, la costumbre de componerlos utilizando ropas de cama o mantelerías ${ }^{98}$, todo lo contrario, eran aderezados por medio de telas con las mejores calidades y de variados motivos ornamentales 99 .

En primer lugar aludiré los altares mencionados, concretamente el de Santa María de la Consolación ${ }^{100}$, frente a la Puerta del Perdón, como se destacaba anteriormente, aún vigente entre las dos puertas del trascoro catedralicio en I539, y el de Santa Lucía ${ }^{\text {Ior }}$, situado en la claustra.

93. «...algunos legos acostumbran sobirse ençima de las gradas de los altares mayores; e otros munchos ocupan las sillas de los asientos del coro... Por ende, hordenamos e mandamos que de aquí adelante ningunt lego de qualquier condiçión que sea, non sea osado de oir misa nin los otros divinales ofiçios en lo alto de las gradas de los dichos altares, nin menos, ninguno suba en los dichos púlpitos; e que, asimismo, non sean osados de ocupar los asientos del coro». Archivo Histórico Diocesano de Jaén. Sínodo Diocesano del Obispo don Luis de Osorio (1492). Título LXXII. Sin foliar.

94. Crónica del Condestable, 1463, p. 107.

95. LÁZARO DAmAS, María Soledad: «El Memorial...», pp. 461, 469, 472.

96. Martínez de MazAs, José: op. cit., p. 195.

97. Crónica del Condestable, apéndice, p. XIII.

98. AHDJ, Sínodo Diocesano del Obispo don Luis de Osorio (1492). Título LXXII. Sin foliar.

99. Como muestra pueden servir los siguientes fragmentos: «E adereçándose çinco altares con sus frontales negros, y cada dos candeleros con sus velas y con sus alfombras en las gradas». Crónica del Condestable, 1464 , p. 197. «Ante el altar de Nuestra Señora de la Consolación... entre las dos puertas del coro, estava puesto un pabellón de seda muy rico». Crónica del Condestable, 1468, p. 308

100. Crónica del Condestable, 1464, pp. 198, 201; 1465, pp. 214, 250.

101. Crónica del Condestable, 1464, p. 152. 
Las fuentes documentales e historiográficas consultadas no permiten confirmar la localización en el templo catedralicio giennense de la claustra o el claustro. $\mathrm{Ni}$ siquiera es posible saber si éstos se refieren a espacios emplazados en el exterior o el interior del mismo, debido fundamentalmente a las múltiples contradicciones existentes al respecto.

He realizado una exhaustiva consulta terminológica de ambos términos a través de los diccionarios de la Real Academia Española (RAE) ${ }^{\mathrm{IO} 2}$, diccionarios histórico-artísticos, arquitectónicos ${ }^{\mathrm{IO} 3}$, y de Autoridades ${ }^{104}$. En general, el vocablo «claustra» se vincula con «claustro», debido al empleo del término latino, plural de claustrum, desaconsejado por la Academia, pero que en ningún caso introduce ningún matiz semántico que permita diferenciarlos conceptualmente.

Llegados a este punto, cualquier referencia lingüística que se haga del término claustra en la catedral giennense que no se refiera a una galería que cerca un patio principal, ha de ser considerada como errónea desde el punto de vista filológico. Podría aceptarse su empleo, si se identifica con el mencionado claustro catedralicio, probablemente emplazado en el espacio correspondiente con la lonja, en paralelo a la calle Campanas, o en su defecto, si se confirmara la existencia de un posible pórtico o nártex, a los pies del templo, en el espacio que hoy ocupa el trascoro, tal y como parece apuntar en sus descripciones el deán Martínez de Mazas ${ }^{105}$.

Del resto de las capillas citadas en los Hechos del Condestable, se han de resaltar los datos que se poseen sobre su vinculación en el templo mayor con su propietario, asociando a ellas un marcado patrocinio, que debiera conferirle un cierto carácter funerario. Prueba de ello lo son las capillas del Señor San Lucas ${ }^{106}$ (propiedad de Miguel Lucas de Iranzo), la de la Condesa ${ }^{107}$, Teresa de Torres, o la de su padre, Carlos de Torres ${ }^{\text {108 }}$. Se corrobora así la pujanza no sólo del Condestable Iranzo, sino también la de la familia Torres en la ciudad de Jaén durante las últimas décadas del siglo xv. En la documentación del año I539 aún persiste una capilla, en la nave del evangelio, propiedad de Luis de Torres, hijo de Miguel Lucas de Iranzo y Teresa de Torres, emplazada junto al sagrario ${ }^{\text {109. }}$. En todas ellas existe un altar, generalmente

102. Todas las ediciones consultadas $(1780,1783,1791,1803,1817,1822,1832,1837,1843,1852,1869,1884,1899$, 1914, 1925, 1927, 1936, 1939, 1947, 1950, 1956, 1979, 1983, 1984, 1989, 1992, 2011) a través de la red en la página de la RAE: http:// www.rae.es.

103. García Salinero, Fernando: Léxico de alarifes de los siglos de oro. Madrid, Real Academia Española, 1968, p. 81; PANiAguA, José Ramón: Vocabulario básico de arquitectura. Madrid, Cátedra, 1978, p. 99; MoraLES Y MARíN, José Luis: Diccionario de términos artísticos. Zaragoza, Octavio y Félez. S.L., 1982, p. 79; PEVSNER, Nikolaus; FLEMING, John; Honour, Hugh: Diccionario de Arquitectura. Madrid, Alianza, 1984, p. 184; Calzada Echeverría, Andrés: Diccionario clásico de Arquitectura y Bellas Artes. Barcelona, Serbal, 2003, p. 225.

104. Claustra. La cerca o cercado, que contiene en sí alguna Iglesia, Convento, Monasterio y Casa de Religión. Es voz poco usada, porque ya se dice más comúnmente Claustro. Es del latino, claustrum. Diccionario de Autoridades. Real Academia Española. Madrid, Gredos, 1976-1979. Vol. 2, p. 27.

105. Martínez de Mazas, José: op. cit., pp. 187-189.

106. Se piensa que emplazada en la nave de la epístola. De ella se aportan datos respecto a las ofrendas realizadas en festividades particulares, como lo era la celebración del día de Todos los Santos. Crónica del Condestable, 1464, pp. 149-151.

107. Crónica del Condestable, 1464, p. 198.

108. Al estar emplazada junto al sagrario, pensamos que se encontraba en la nave del evangelio. Ibidem.

109. Es posible que fuera la misma capilla que en décadas anteriores fuera propiedad de su abuelo, Carlos de Torres. No obstante, su labor fue más allá, como se aprecia con la fundación de nuevas capellanías a comienzos del 
con unas gradas. Este elemento mobiliar es un signo claro de su utilización como un espacio en el que es posible desarrollar determinadas actividades de culto. Así se aprecia cuando por ejemplo tienen lugar las celebraciones matrimoniales de algunos de los criados del Condestable en la llamada capilla del Capellán mayor ${ }^{\text {IIO }}$. En su interior, en ocasiones concretas, se emplazaban determinados objetos preferentemente de madera (hachas y candeleros) con finalidades meramente rituales.

Otras capillas mencionadas son la de Santiago ${ }^{\text {III }}$, con la información de su vinculación espacial con la capilla del señor San Lucas, a la que se encontraba anexa, estando posiblemente localizada en la nave de la epístola. La capilla del Sagrario ${ }^{\mathrm{II}}$, limítrofe con la de Carlos de Torres, y finalmente la capilla del cabildo, que Morales Gila sitúa en la nave de la epístola, identificándola con la capilla de San Pedro de Osma ${ }^{\mathrm{II}}$. Precisamente sobre ella, Cazabán Laguna, recogiendo los datos citados por Francisco de Bilches, comenta su existencia ya en el año I457, vinculada particularmente con las reuniones del cabildo catedralicio, incidiendo en el tema de su denominación como consecuencia de los canónigos sorianos venidos a la Diócesis, una vez finalizada la conquista:

...a la hora de misa del jueves 4 (agosto 1457) estaban ya en la capilla de San Pedro de Osma, situado cerca del presbiterio cerrado de la catedral vieja, en donde el cabildo se reunía. (...) En el espacio de la capilla de San Pedro de Osma, cuyo era un altar existente desde que a Jaén vinieran los primeros obispos, naturales de Soria ${ }^{114}$.

Veintiún años después, en los estatutos catedralicios compilados en tiempos del obispo don Iñigo Manrique, su localización se relaciona con la anteriormente citada claustra catedralicia ${ }^{\mathrm{II}}$.

En esta segunda década del siglo xv cobra cada vez más fuerza la consideración de la Catedral como relicario del Santo Rostro, de ahí que en la Crónica del Condestable se refieran los momentos expresos en los que se mostraba, para su veneración, tan insigne reliquia, convirtiendo su exhibición en un elemento de distinción social, dado que en ocasiones sólo podía ser contemplada por las personalidades más relevantes del momento ${ }^{116}$.

siglo XVI. AHDJ, Capellanías. Fundación de dos capellanías en la capilla de Santa María Magdalena, del mayorazgo de Torres, en la catedral de Jaén. Citado en: LÁZARo DAmAS, María Soledad: «La Catedral de...», p. 98; LÁZARO DAMAS, María Soledad: «La Catedral medieval...», p. 85.

110. Prueba no sólo de la interpretación de un papel, casi a la altura de un virrey que protege y apoya a los miembros de su «corte», sino de la propia jerarquización espacial. Así frente a las celebraciones matrimoniales de Miguel Lucas y Teresa de Torre, desarrolladas en el altar mayor de la Catedral, los criados, carentes de su condición, celebran sus esponsales en emplazamientos secundarios, como parece ser que así lo era la capilla del Capellán mayor. Crónica del Condestable, 1463, p. 113.

111. Crónica del Condestable, 1464, p. 198.

112. Ibidem.

113. Morales Gila, Paula: op. cit., p. 343.

114. Cazabán Laguna, Alfredo: op. cit,. p. 258.

115. «Fueron feneçidos los dichos estatutos, miércoles diez días del mes de Junio, año del nacimiento de Nuestro Señor Jhesucristo de mill e quatrocientos e setenta e ocho años... estando en la capilla de Sant Pedro de Osma, que es en la claustra de dicha iglesia, ayuntados a cabildo». Rodríguez MolınA, José: «Estatutos de...», p. 142.

116. Crónica del Condestable, 1461, pág. 50; 1464, p. 195. 
La complicada historia constructiva de la catedral giennense y las carencias documentales de la época a la que me he referido dejan aún bastantes interrogantes sin resolver. En cualquier caso, a través de este artículo se ha pretendido plantear una serie de aportaciones derivadas de la incorrecta lectura historiográfica, fruto de la repetición de planteamientos e hipótesis, que, ante la falta de nuevas noticias al respecto, han sido reiterados en un sinfín de trabajos, sin haberse realizado el más mínimo cuestionamiento crítico (FIGURA 7).

De esta forma, las aportaciones de este trabajo pretenden aclarar algunas de las dudas planteadas al respecto del proceso de transformación de la aljama en Catedral, y la peculiar historia de algunos de sus elementos originales: su coro, cuya emplazamiento, a la manera de schola cantorum, permite vincularlo al de la catedral de Toledo, sus accesos y su primitiva torre, relacionados con los problemas emanados del emplazamiento de la muralla, o la problemática terminológica al respecto de los conceptos de claustra y claustro.

Por otro lado, las atinadas intervenciones de los prelados que dirigieron la Diócesis en este momento fueron cruciales para el devenir de una fábrica medieval, demostrando con sus actuaciones el deseo de manifestar el reconocimiento del prestigio personal alcanzado, pasando a la historia como algunos de los grandes protagonistas de tan magna obra, que, pese a sus desapariciones y evidentes transformaciones, no ha perdido el más mínimo interés en la comunidad científica. 


\section{PLANTA DE LA CATEDRAL DE JAÉN}
A. Coro
B. Presbiterio
C. Crucero
D. Antesacristía
E. Sacristía
F. Sala Capitular
G. Sagrario
H. Fachada Principal
I. Portada Sur
J. Portada Norte

\section{CAPILLAS}

1. Capilla de Santo Domingo de Guzmán

2. Capilla de San Juan Nepomuceno y San Sebastián

3. Capilla de San Jerónimo

4. Capilla de la Virgen de los Dolores

5. Capilla de la Virgen de las Angustias

6. Capilla de Santa Teresa

7. Capilla de San Benito

8. Capilla de Santiago

9. Capilla Mayor o del Santo Rostro

10. Capilla de San Fernando

11. Capilla de San Eufrasio

12. Capilla de la Inmaculada

13. Capilla del Niño Jesús

14. Capilla de San Miguel Arcángel

15. Capilla de San Pedro Pascual

16. Capilla del Cristo del Refugio y Virgen de la Correa.

17. Capilla de San José
Finales S. XV - Principios S. XVI
$1667-1702$
Vandelvira, 1551 - 1575
$1701-1726$
$1635-1660$
$1726-1802$

K

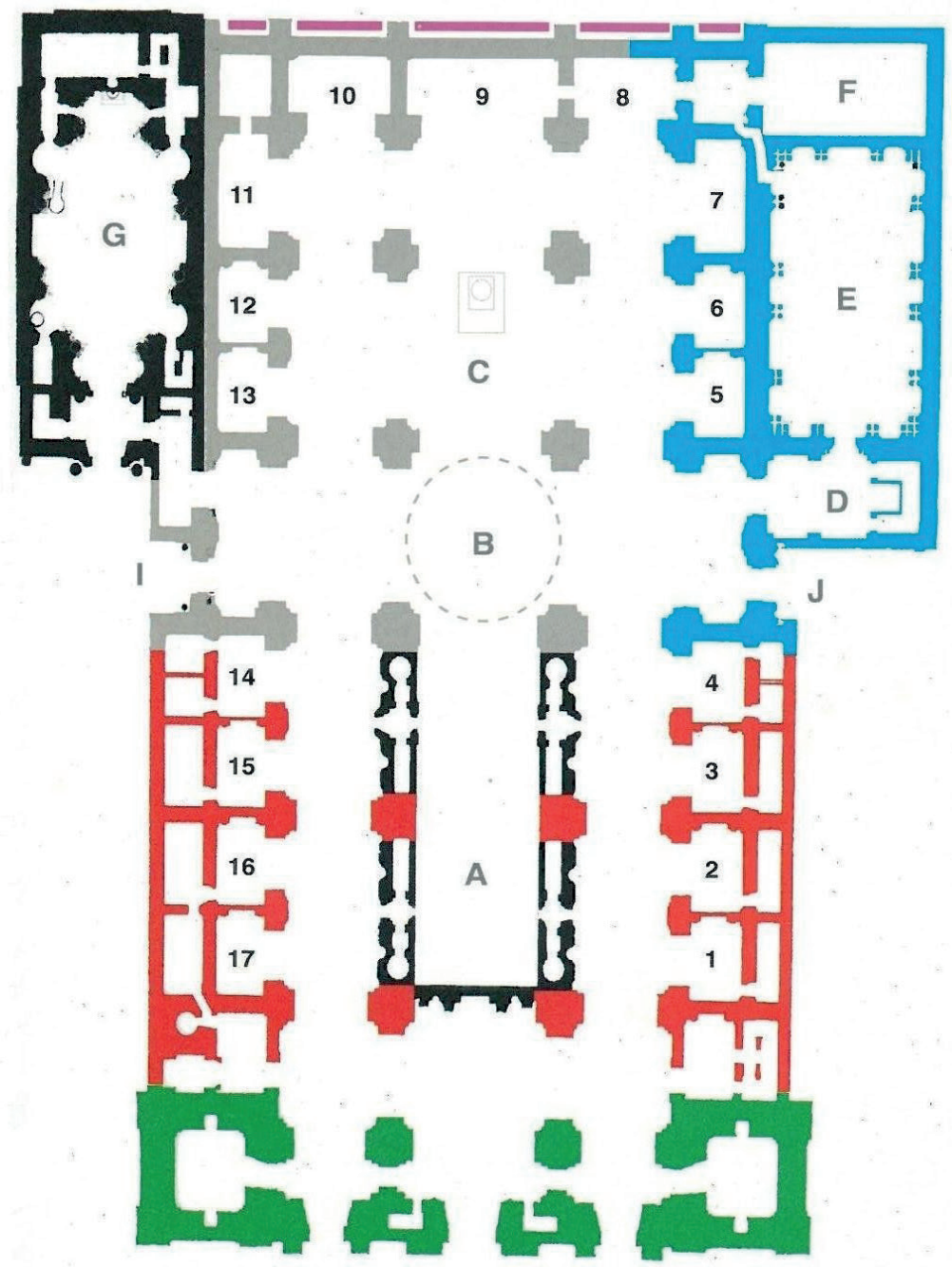

H

FIGURA 7. PLANTA ACTUAL DE LA CATEDRAL DE JAÉN

Guerrero \& Serrano (2011), pp. 122-123. 


\section{BIBLIOGRAFÍA}

Almagro Gorbea, Antonio: «De Mezquita a Catedral. Una adaptación imposible», en JimÉNEZ MARTín, Antonio (ed.): La piedra postrera. Simposium Internacional sobre la Catedral de Sevilla en el contexto del gótico final. Sevilla, Taller Dereçeo, 2007 pp. 24-3I.

Aragón Moriana, Arturo: «Iconografía del Santo Rostro en la Catedral giennense» Alto Guadalquivir, I7 (I993), pp. 34-35.

Del Arco Moya, Juan: «La planta de la Catedral de Jaén de Juan de Aranda», Códice, 20 (2007), pp. 37-44.

DE BILCHES, Francisco: Santos y santuarios del Obispado de Jaén y Baeza. Jaén, Impresión Domingo García Morras, 1653.

CAZABÁn Laguna, Alfredo: «De cómo entró en Jaén el Sr. D. Alonso Vázquez de Acuña», Don Lope de Sosa, 3, I9I3, p. 258.

Calzada Echeverría, Andrés: Diccionario clásico de Arquitectura y Bellas Artes. Barcelona, Serbal, 2003.

Chueca Goitia, Fernando: Invariantes castizos de la arquitectura española. Madrid, Seminarios y Ediciones, I97I.

Cuevas Mata, Juan, Del Arco Moya, José \& Del Arco Moya, Juan: Relación de los Hechos del muy magnífico e más virtuoso, el Señor don Miguel Lucas, muy digno Condestable de Castilla, Jaén, Universidad y Ayuntamiento de Jaén, 20oI.

FERNÁNDEZ GonZÁLEZ, Etelvina: «Del santo Mandilyon a la Verónica: sobre la vera icona de Cristo en la edad media», en vV.AA: Imágenes y promotores en el arte medieval: miscelánea en homenaje a Joaquín Yarza Luaces. Barcelona, Universidad Autónoma, 200I, pp. 353-37I.

Galera Andreu, Pedro Antonio: La Catedral de Jaén. Madrid, Everest, I983.

- «La Verónica, «objeto» de peregrinación en España», en vV.AA.: Actas del vi Congreso Español de Historia del Arte. Los Caminos y el Arte. Santiago de Compostela, I986. Santiago de Compostela, Universidad, I989, pp. 42I-432.

- Las Catedrales de Vandelvira. Úbeda, El Olivo, 2006.

Galera Andreu, Pedro Antonio \& Ruiz Calvente, Miguel: Corpus documental para la historia del arte en Jaén. Arquitectura del siglo XVI (I). Jaén, Universidad, 2006.

García Salinero, Fernando: Léxico de alarifes de los siglos de oro. Madrid, Real Academia Española, 1968.

Gómez Moreno, Manuel: «La sillería del coro de la Catedral de Jaén», Arte Español, 3, Madrid, I94I, pp. 3-6.

Guerrero Villalba, Carmen \& Serrano Estrella, Felipe: Conoce la Catedral. Jaén, Universidad, 20II.

IBN AL-JATiв, Muhammad: Historia de los Reyes de la Alhambra. El resplandor de la luna llena (Al-lamha al-badriyya). Granada, Universidad, I998.

JóDAR Mena, Manuel: «El derecho de patronazgo y la capilla mayor de la Catedral de Jaén: aportaciones documentales de la casa de Santisteban del Puerto», en RAmalló Asensio, Germán (coord.): Actas del Congreso: El Comportamiento de las Catedrales españolas. Del Barroco a los Historicismos, Murcia, 2002. Murcia, Universidad, 2003. 
Laguna PAul, Teresa: «La aljama cristianizada. Memoria de la catedral de Santa María de Sevilla», en vv.AA: Metropolis Totius Hispaniae. 750 Aniversario de la Incorporación de Sevilla a la Corona de Castilla. Sevilla, Ayuntamiento, I998, pp. 4I-7I.

LÁzaro Damas, María Soledad: «La catedral de Jaén según el libro de visitas de I539», Boletín del Instituto de Estudios Giennenses, I70 (1998), pp. 95-I27.

- «El memorial de la torre del Alcotón. Un interesante expediente para el estudio de la obra nueva renacentista de la catedral de Jaén», Giennium, 8 (2005), pp. 463-488.

- «La Catedral medieval y la obra nueva tardogótica. Los proyectos de los obispos Osorio y Fuente del Sauce», en DEl Arco Moya, Juan (coord.): Andrés de Vandelvira. Vida y obra de un arquitecto del Renacimiento. Jaén, Ayuntamiento, 2006, p. 76-85.

Levi-ProvençAl, Evariste: Le Péninsule Ibérique au Moyen Age, d'après le Kitab ar-Rawod al mi'tar fi habar al-aktar d'Ibn 'Abd-al-Mun'im al-Himyari [Texto impreso]: texte arabe des notices relatives à l'Espagne, au Portugal et au Sud-Ouest de la France. Leiden, E.J. Brill, I938.

López ARANDiA, María Amparo: «Aproximación a un tratado ilustrado sobre el Santo Rostro de Jaén», Boletín del Instituto de Estudios Giennenses, I7I (I999), pp. 29-45.

López Pérez, Manuel: El Santo Rostro de Jaén. Córdoba, Cajasur, I995.

MARTÍNEZ de MAZAS, José: Retrato al natural de la ciudad de Jaén y término de Jaén. Barcelona, Imprenta D. Pedro de Doblas, I794. Reimpresión: Barcelona, El Albir, I978.

Martínez Rojas, Francisco Juan: Aproximación a la Historia de la Iglesia. Jaén, Obispado, I999.

- «Novam Ecclesiam egregia structura facere. Documentos episcopales y pontificios para la construcción de la Catedral de Jaén I (Siglos XV-XvI)», Giennium, 2 (I999), pp. 342-343.

Montijano Chica, Juan: «El Santo Rostro y la Catedral de Jaén», Alto Guadalquivir, 4 (I980), pp. 24-25.

- Historia de la Diócesis de Jaén y sus obispos. Jaén, Instituto de Estudios Giennenses, I986.

Morales Gila, Paula: «La catedral de Jaén en la época del condestable don Miguel Lucas de Iranzo», en SÁnchez López, Juan Antonio \& Coloma Martín, Isidoro. (coords.): Correspondencia e integración de las artes: $14 .{ }^{\circ}$ Congreso Nacional de Historia del Arte. Vol. I. Madrid, Ministerio de Educación, Dirección de Cooperación y Comunicación Cultural, 2003, pp. 337-344.

MORALES y Marín, José Luis: Diccionario de términos artísticos. Zaragoza, Octavio y Félez. S.L., I982.

Navascués Palacio, Pedro: «Los coros catedralicios españoles», en Yzquierdo Perrín, Ramón (ed.): Los coros de catedrales y monasterios: arte y liturgia. A Coruña, Fundación Pedro Barrié de la Maza, 200I, pp. 25-4I.

Nieto Cumplido, Manuel: La Catedral de Córdoba. Córdoba, Obra social y cultural de Cajasur, 1998.

NúÑEZ DE Sotomayor, Juan: Descripción panegyrica de las insignes fiestas que la S. Iglesia Catedral de Iaén celebró en la traslación del S. Sacramento a su nuevo y sumptuoso Templo por el mes de octubre de I660. Málaga, impreso por Mateo López Hidalgo, I66I.

Ortega Suca, Antonio. La Catedral de Jaén: unidad en el tiempo. Jaén. Colegio Oficial de Arquitectos de Andalucía Oriental, I99I.

Paniagua, José Ramón: Vocabulario básico de arquitectura. Madrid, Cátedra, I978.

Pérez GonzÁlez, Carlos: «El culto a las reliquias en la Edad Media: historia de una tradición pagana con continuidad en la religión cristiana», I6. ${ }^{a}$ Jornadas de Filología Clásica de las Universidades de Castilla y León, Burgos, 2002, Ruiz Sola, Aurelia \& Pérez GonZÁlez, Carlos (dirs.): Burgos, Universidad, 2003, pp. 167-193. 
Pevsner, Nikolaus, Fleming, John \& Honour, Hugh: Diccionario de Arquitectura. Madrid, Alianza, I984.

PonZ, Antonio: Viage de España, en que se da noticia de las cosas más apreciables, y dignas de saberse, que hay en ella. Edición facsímil: Madrid, Viuda de D. Joaquín Ibarra, I79I.

RiverA, Juan Francisco: «Notas y documentos para el episcopologio de la Sede de Baeza-Jaén, los siglos xill y XIV», Boletín del Instituto de Estudios Giennenses, 80 (I974), pp. 9-74.

Rodríguez Molina, José: El Reino de Jaén en la Baja Edad Media. Aspectos demográficos y económicos. Granada, Universidad, 1978.

— «Estatutos de la Catedral de Jaén: recopilación de I478», Boletín del Instituto de Estudios Giennenses, 85-86 (1975), pp. 9-186.

Rosell, Cayetano: Crónicas de los reyes de Castilla [Texto impreso]: desde don Alfonso el Sabio hasta los Católicos don Fernando y doña Isabel. Madrid. Sucesores de Hernando I919-I93I. Madrid, Atlas, I953.

Salvatierra Cuenca, Vicente: La formación de la ciudad de Jaén. De Ibrahim ibn Hamusk al Condestable Iranzo. Jaén, Instituto de Estudios Giennenses, 2007.

Toral y Fernández de PeÑaRAnda, Enrique: «El comendador don Sebastián Rodrigo de Biedma y Narváez y su descripción de las obras de la catedral nueva de Jaén», Boletín del Instituto de Estudios Giennenses, I02 (1980), pp. 57-70.

TORRES JIMÉNEZ, Juan Carlos: «El ataque nazarí a Jaén de I367-I368 y las religiosas del convento de Santa Clara», Giennium (2007), p. 455-48I

Turatti Guerrero, Rafael: «La quema de los archivos de Jaén en I368 ¿Moros de Granada o Pedro 1?», en Toro Ceballos, Francisco \& Rodríguez Molina, José: (coords).: Historia, tradiciones y leyendas en la frontera: IV Estudios de Frontera, Alcalá la Real, 200I. Jaén, Diputación Provincial, 2002, pp. 579-592.

De Ulierte VÁzquez, María Luz: El retablo en Jaén (I580-I80o). Jaén, Ayuntamiento, 1986.

de Ximena Jurado, Martín: Catálogo de los Obispos de las Iglesias Catedrales de Jaén y Anales Eclesiásticos de este Obispado. Edición facsímil. Granada, Universidad, I99i. En Madrid: por Domingo Garcia y Morràs, I654. 


\section{Dossier Cómplices Necesarios por Carlos Reyero Hermosilla - Dossier Necessary Accomplices by Carlos Reyero}

2) CARLOS REYERO

Introduction: Necessary Accomplices / Presentación: Cómplices necesarios

25 Encarna Montero Tortajada

The Oligarch and the Brushes: a Biographical Sketch of Andreu Garcia, priest / El oligarca y los pinceles: breve semblanza del presbítero Andreu Garcia

María Alegra García García

Some aspects about archbishop of Toledo don Juan Martínez Silíceo's iconography (c.1477-1557) / Algunos aspectos en torno a la iconografía del arzobispo de Toledo don Juan Martínez Silíceo (c.1477-1557)

\section{FELIPE PEREDA}

Performing Doubt: the Art of Believing in Early Modern Spain / El ejercicio de la duda: el arte de creer en la España alto Moderna

\section{Jesús-PEdRo LoREnTE LORENTE}

The mouseion ideal reinterpreted as art colony on the outskirts of Darmstadt and Hagen / El ideal del mouseion reinterpretado como colonia artística en las afueras de Darmstadt y Hagen

\section{9}

NÚRIA FERNÁNDEZ RIUS \& NURIA PEIST

The photographic and the mediation system. Artistic, technical and commercial values in the beginning of photography / Lo fotográfico y el sistema mediador. Valores artísticos, técnicos y comerciales en los inicios de la fotografía

\section{Elena Marcén Guillén}

Real museum, imaginary museum. Considerations around the concept of museum as metamorphosis scenery / Museo real, museo imaginario. Reflexiones en torno al concepto de museo como escenario de metamorfosis

147 VICENÇ FURIÓ

Fame and prestige: necessary and decisive accomplices in the case of Hilma af Klint / Fama y prestigio: cómplices necesarios y decisivos en el caso de Hilma af Klint

\section{Miscelánea $\cdot$ Miscellany}

De la aljama a la primitiva construcción gótica. Reflexiones a propósito de la Catedral de Jaén en época bajomedieval / From the Great Mosque to the former Gothic construction. Some observations on Jaén's Cathedral during the late middle ages
199

TERESA IZQUIERDO ARANDA

Carpintero y maestro constructor en la arquitectura gótica valenciana / Carpenters and building mason in the Gothic architecture in Valencia $\left(14^{\text {th }}-15^{\text {th }}\right.$ centuries)

223

ANTONIO JosÉ DíAZ FERNÁNDEZ

El arquitecto madrileño Pedro de la Torre en Toledo y un retablo inédito localizado / The Architect of Madrid Pedro de la Torre in Toledo and a located unpublished altarpiece

24.7 Fernando R. Bartolomé García \& Laura Calvo García

Transformaciones en el retablo mayor de San Miguel Arcángel de Lazkao (Gipuzkoa). Del Barroco al Neoclasicismo / Changes in the main altarpiece of Saint Michael the Archangel in Lazkao (Gipuzkoa). From Baroque to Neoclassicism

\section{Francisco JaVIER LÁZARO SEBAStiÁN}

La renovación de la fotografía española a partir de la pauta estética del realismo. Un precedente formal y significativo en el reportaje de Eugene Smith sobre Deleitosa (Cáceres) / The renovation of the Spanish photography from the aesthetic guideline of the realism. A formal and significant precedent in Eugene's Smith photographic article on Deleitosa (Cáceres)

277 Javier Cuevas del Barrio

El posicionamiento de Sigmund Freud ante el Surrealismo a través de la correspondencia con André Breton / The position of Sigmund Freud regarding Surrealism through correspondence with André Breton

295 Alicia SÁnCHEZ ORTIZ

El vacío iluminado del negro / The illuminated void of black

317 Óscar MuÑoz Sánchez

Santiago Serrano (1970-1980): Hacia una pintura no aprehensible / Santiago Serrano (1970-1980). Towards a non-apprehensible painting

347 Antonio Jesús Sánchez FERnÁndeZ

Restauración y metamorfosis de los valores del patrimonio cultural / Restoration and Metamorphosis of the Values of Cultural Heritage

\section{Reseñas · Book Review}

375

Aricò, Nicola. Architettura del Tardo Rinascimento in Sicilia. Giovannangelo Montorsoli a Messina (1547-57). Firenze, Leo S. Olschi Editore, 2013. (AlICIA CÁmARA MuÑoz)

Combalía, Victoria. Dora Maar. Barcelona, Circe, 2013. (AMPARO SERRANO DE HARO)

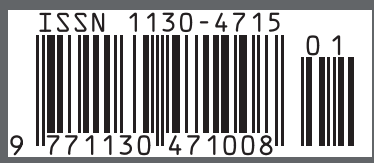

